\title{
Distribution of porphyry copper deposits along the western Tethyan and Andean subduction zones: Insights from a paleotectonic approach
}

Guillaume BERTRAND ${ }^{\mathrm{a}, \mathrm{b}, \mathrm{c}\left({ }^{*}\right)}$, Laurent GUILLOU-FROTTIER ${ }^{\mathrm{a}, \mathrm{b}, \mathrm{c}}$ and Christelle LOISELET ${ }^{\mathrm{a}, \mathrm{b}, \mathrm{c}}$

\author{
${ }^{a}$ BRGM, ISTO, UMR 7327, 45060 Orléans, France \\ ${ }^{\mathrm{b}} \mathrm{CNRS} / \mathrm{INSU}$, ISTO, UMR 7327, 45071 Orléans \\ ' Université d'Orléans, ISTO, UMR 7327, 45071 Orléans
}

Revised manuscript submitted to Ore Geology Reviews - December 20th, 2013

$\left({ }^{*}\right)$ Corresponding author: Guillaume BERTRAND, BRGM, ISTO, UMR 7327, Georesources Division, 3 av. C. Guillemin, 45060 Orléans Cedex 2, France; g.bertrand@brgm.fr; tel: +33238643669 ; fax : +33 238643402 


\begin{abstract}
Along the western Tethyan and Andean subduction zones the distribution of Cretaceous and Cenozoic porphyry $\mathrm{Cu}$ deposits is not random and shows that they were emplaced in distinct regional clusters. To understand the appearance of these clusters within their geodynamical contexts and identify kinematic features which would favor the genesis of porphyry-type ore bodies, we use a paleotectonic approach. Two clusters in the Aegean-Balkan-Carpathian area, which were emplaced in upper Cretaceous and Oligo-Miocene, and two others in the Andes, which were emplaced in late Eocene and Miocene, are sufficiently well constrained to be studied in detail. It appears that they are associated with a specific polyphased kinematic context related to the convergence of tectonic plates. This context is characterized by: 1) a relatively fast convergence rate shortly followed by 2) a drastic decrease of this rate. From these observations, and assuming that the major part of plate convergence is accommodated along subduction zones, we propose a two-phase geodynamic model favoring emplacement of porphyry $\mathrm{Cu}$ deposits: 1) a high melt production in the mantle wedge, followed by 2) an extensional regime (or at least relaxation of the compressional stress) in the upper plate, promoting ascension of fertile magmas to the upper crust. Melt production at depth and the following extensional regime, which would be related to variations in convergence rate, are thus associated with variations in plate and trench velocities, themselves being controlled by both plate kinematics at the surface and slab dynamics in the upper mantle. In particular, along-strike folding behavior of the subducting slab may strongly influence trench velocity changes and the location of porphyry $\mathrm{Cu}$ deposits. Metallogenic data suggest that periods of slab retreat, which would favor mineralization processes during $\sim 40$ Myrs, would be separated by barren periods lasting $\sim 10$ to 20 Myrs, corresponding to shorter episodes of trench advance, as observed in laboratory experiments. These results confirm the control of the geodynamic context, and especially subduction dynamics, on the genesis of porphyry $\mathrm{Cu}$ deposits. This study also shows that the paleotectonic approach is a promising tool that could help identify geodynamic and tectonic criteria favoring the genesis of various ore deposits.
\end{abstract}

Keywords: porphyry Cu deposits, paleotectonics, subduction, slab dynamics, Tethys, Andes 


\section{1 - Introduction}

Assessing the most favorable areas for mineral prospecting has always been a major concern for exploration geologists. The spatial approach of mineral resources predictivity focuses on the geological context of ore deposits and on distinct parameters that control their distribution, from district to continental scales, defined from geology, tectonic structures, geophysics and geochemistry (e.g. Cassard et al., 2008; Carranza, 2011) but also geodynamics and paleogeography (Scotese et al., 2001). It is an upstream phase of prospection campaigns, the goal of which is to guide exploration strategy by predicting a priori the most favorable areas.

Porphyry $\mathrm{Cu}$ deposits were studied and described by many authors (see the reviews by e.g. Seedorff et al., 2005, and Sillitoe, 2010). They are closely linked to their geodynamic surroundings and are most often associated with calc-alkaline and adakitic magmatism in subduction zones (e.g. Burnham, 1979; Cline and Bodnar, 1991; Thieblemont et al., 1997). These deposits result from a dual melting process with: 1) an initial melting in the metasomatized mantle wedge, above the subducting oceanic slab, which generates relatively oxidized and sulfur-rich mafic magmas with incompatible chalcophile or siderophile elements (such as $\mathrm{Cu}$ or $\mathrm{Au}$ ), and 2) a secondary melting by injection of dykes and sills in the MASH (Melting, Assimilation, Storage, Homogeneization) zone of the lower crust, yielding a crustal- and mantle-derived hybrid magma, with a high content of volatile and metalliferous elements, and a density that is low enough to allow its upward migration through the crust (Richards, 2003, 2011). They are generally associated with plutonic apexes of granitic bodies (e.g. Burnham, 1979; Shinoara and Hedenquist, 1997; Cloos, 2001; Guillou-Frottier and Burov, 2003) emplaced in the upper crust of the overriding plate (usually 1-4 km depth). Ore grades are often low, but volumes can be huge, which can possibly make them very large deposits (e.g. El Teniente, Chuquicamata or Rio Blanco-Los Bronces, all in Chile, with 78.6, 65.2 and 52.4 Mt of copper respectively; Jébrak and Marcoux, 2008). In addition, porphyry Cu deposits can yield valuable new-technology metals, such as rhenium which is used in strong high-temperature resistant alloys and often produced as by-product of molybdenum (e.g. Melfos et al., 2001; Berzina et al., 2005).

For more than 40 years, authors have demonstrated relationships between tectonics and mineralizing processes (e.g. Sillitoe, 1972, and compilation by Wright, 1977). The new paradigm of plate tectonics, along with numerous metallogenic studies, allowed proposals of new genetic models linking the lithosphere and mantle dynamics to the occurrence of deposits (e.g. Mitchell and Garson, 1981; Sawkins, 1984; Barley et al., 1998; Tosdal and Richards, 2001; Kerrich et al., 2005; Bierlein et al., 2006). Although the close relationship between porphyry Cu deposits and subduction zones is well established, there is, however, no consensus on which subduction parameters primarily control the genesis of porphyry deposits. This is not surprising since, following decades of seismic tomography and modeling studies, distinct modes of lithosphere 
deformation have been suggested and the number of physical parameters controlling the subduction process has continuously increased (slab density, mantle viscosity, slab to mantle viscosity ratio, etc). The way the subducted lithosphere behaves beneath the overriding plate appears to depend not only on these physical properties but also on plate features at the surface (plate velocity, slab dip angle, amount of retrograde motion, varying ages along trench, etc). Deep subducting lithosphere behavior is also controlled by plate motion and plate layout at the surface (Yamato et al., 2009). One objective of this study, rather than promoting a single parameter as key to ore formation, is to investigate what control a single selected process, subduction dynamics, has on formation of porphyry Cu deposits.

In the Tethys belt it is widely accepted that the genesis of many types of mineralization is closely linked to the geodynamic context (e.g. de Boorder et al., 1998; Lescuyer and Lips, 2004; Lips, 2007). Neubauer et al. (2005) and Loiselet et al. (2010a) have shown the strong impact of the geometry and dynamics of the eastern Mediterranean subduction on the distribution of porphyry and epithermal deposits in the Carpathian and Aegean regions. Similarly, in the Andes numerous studies have suggested specific relationships between subduction parameters and the occurrence of porphyry $\mathrm{Cu}$ deposits: conditions of flat-slab subduction (Kay and Mpodozis, 2001; Billa et al., 2004), stress relaxation and transtensional structures (Richards et al., 2001). In particular, the convergence configuration between the subducting and the overriding plates (velocities and obliquity) would dictate how mineralized bodies emplace in the shallow crust (Tosdal and Richards, 2001). Rosenbaum et al. (2005) have suggested that subduction of topographic anomalies (ridges and plateaus) triggered the formation of ore deposits. According to Cooke et al. (2005), topographic and thermal anomalies on the subducting slab could trigger the formation of giant porphyry deposits. All these studies clearly show that past subduction history and, in particular, the convergence parameters have to be accounted for when genesis of porphyry $\mathrm{Cu}$ deposits is studied.

To identify relationships between mineralization and geodynamic processes, it is, thus, necessary to place the mineralization within the geodynamic framework that prevailed at the time of its genesis. It is a necessary step to better understand the relationships between the mineralization itself and its environment (plate boundaries, tectonic structures, stress and strain regimes, geology, etc.). This would, in turn, help identify criteria that are favorable to its genesis. The present study aims at better understanding of the geodynamic parameters, in terms of plate kinematics and slab dynamics, that could favor the genesis of porphyry Cu deposits in subduction contexts. For this, we have focused our analysis on two mineralized subduction zones: the western Tethyan suture and the Andean subduction zone. We have adopted a paleotectonic approach, which has been little used so far in the field of metallogeny, to study past geodynamic contexts and plate kinematic patterns. This approach is coupled with results from laboratory experiments to assess the 3D slab dynamics and its possible relationships with plate kinematics and deposit 
genesis.

\section{2 - Subduction dynamics and convergence rates}

\subsection{Dynamics and deformation of the subducting lithosphere}

Dynamics of subduction zones is governed by the balance between driving forces (i.e. slab pull, ridge push), resisting forces (i.e. viscous shear and viscous resistance in the mantle) and other external forces due to the large-scale mantle flow or to density contrasts created by phase transitions in the mantle (e.g. Heuret and Lallemand, 2005; Billen, 2008; Husson, 2012). Relative magnitude of these forces determines surface plate kinematics, including the possibility of trench retreat or advance episodes. Variations in plate velocity at the surface are one consequence of the deformation of the subducting lithosphere in the mantle. In the particular case of trench retrograde motion, trench curvature is one of the surface signatures of the longitudinal plate deformation that results from the interaction between subducting lithosphere and surrounding mantle flow (Schellart, 2004; Morra et al., 2006; Funiciello et al., 2006; Loiselet et al., 2009). The various observed plate curvatures (Figure 1) are mainly due to plate physical properties (i.e. density, viscosity), dimensions (Dvorkin et al., 1993), and internal heterogeneities (Morra et al., 2006). Longitudinal plate deformation can also be inferred from laterally varying slab dips within the same plate (e.g. Hayes et al., 2012). Furthermore, deformation of the subducting lithosphere along the mantle transition zone at $660 \mathrm{~km}$ depth has been suggested to control trench kinematics (Goes et al., 2008).

At greater depth, thanks to more than two decades of seismic tomography studies, different deformation modes of the subducted lithosphere have been suggested (van der Hilst et al., 1991; Fukao et al., 1992). The $660 \mathrm{~km}$ mantle discontinuity (phase transition zone) imposes a viscosity contrast between the upper and lower mantles, creates a resisting force preventing the subducted slab to penetrate straightly into the lower mantle (Kincaid and Olson, 1987), and induces viscous slab deformation along the interface. Tomography images have illustrated horizontally spreading slabs above the mantle transition zone (e.g. Japan subduction zone, Sandwich subduction zone) but also thickening and vertically sinking slabs into the lower mantle (e.g. Marianas subduction zone). Intermediate deformation modes involving thickened pile of buoyant material around the transition zone (e.g. Java subduction zone) have been successfully reproduced by laboratory and numerical experiments (Griffiths et al., 1995; Guillou-Frottier et al. 1995; Christensen, 1996; Houseman and Gubbins, 1997). In particular, the folding mode allows the accumulation of dense subducted folded lithosphere together with light upper mantle material trapped in between folds. This folding behavior has been increasingly invoked to explain tomography images of thick blue zones near the mantle transition zone (Ribe et al., 2007), and to interpret seismic data on focal 
mechanisms (Myhill, 2013).

When the folding regime is described, the 3D character due to along-strike - and not only down-dip - undulations (hereafter considered as "buckling" behavior) is rarely invoked. However, a few recent studies suggested that the slab buckling process may be more common than previously thought. This dynamic mechanism would occur in many subducting plates and would be a natural consequence of the Earth sphericity (Stegman et al., 2010; Morra et al., 2012). According to Schettino and Tassi (2012), lateral deformation of the subducting lithosphere is directly related to plate bending along an arcuate trench, but the mantle transition zone would also play a key role on the 3D deformation of slabs (Loiselet et al., 2010b). Although recent 3D numerical models investigated the temporal evolution of the subducting lithosphere (e.g. Schellart et al., 2007; Jadamec and Billen, 2010; Morra et al., 2012), the buckling process was seldom described or quantified. We present below one laboratory experiment where the viscosity jump at the mantle transition zone induces a resisting force to slab penetration, triggering a large-scale buckling behavior in the upper mantle. Consequences on plate velocity changes at the surface (trench retreat or advance) are then described.

\subsection{Slab buckling in the laboratory}

Figure $2 \mathrm{a}$ illustrates one of the laboratory experiments by Guillou-Frottier et al. (1995), in which 3D features were not described. These experiments were scaled to Earth's parameters in terms of Peclet number (experiments were kinematically- and thermally-scaled) and contrasts in physical properties. A viscous, dense and cold slab (red material in Figure 2a) is injected at a controlled velocity within a less viscous upper layer, which lies over a more viscous and denser lower layer. The lower layer is 44 times more viscous than the upper layer and a density contrast of $4 \%$ is imposed. When scaled to the Earth, the series of pictures show 83 Myrs of subduction. Plate velocity corresponds to $3.3 \mathrm{~cm} / \mathrm{yr}$ and a retrograde (rollback) velocity of $1 \mathrm{~cm} / \mathrm{yr}$ is imposed (see details in Guillou-Frottier et al., 1995). As illustrated on each picture along distinct parts of the subducted slab, one can see and quantify the temporal evolution of the 3D buckling slab. Dark and grey lines underline varying subduction angles induced by the interaction between the slab and the lower layer. A longitudinal cross-section of the slab at a fixed depth - shown by a white dashed line - presents a lateral undulation of the entire slab (black thick lines on map views at the right of each picture), representing the along-strike folding mode (or buckling mode). Here, we, thus, emphasize the $3 \mathrm{D}$ character of the buckling slab induced by the slab-transition zone interaction (Figure $2 \mathrm{~b}$ ). The forming bulge of the subducting slab favors the trench advance while, at the same time, slab edges sink more easily and induce a trench retreat at the surface (see arrow in the bottom-right picture of Figure 2a). In other words, lateral and temporal variations in subduction dip angle in the upper mantle (buckling behavior) are expressed at the surface by trench advance or retreat episodes (see also Morra et al., 2012). Contrarily to what Faccenna et al. (2007) and Di Giuseppe 
et al. (2008) suggested, the slab/upper mantle viscosity ratio - which is not necessarily high (Loiselet et al., 2009; Schellart, 2010) - is probably less important (in the back-transmit resistance to motion from the $660 \mathrm{~km}$ discontinuity to the shallow subduction zone) than the presence of a viscous lower mantle, which tends to decrease the slab sinking velocity (Ricard et al., 1993; Butterworth et al., 2014). With time, the stagnant pile of subducted material into the lower mantle maintains and enhances the resisting force to slab penetration, and thus affects the buckling behavior within the upper mantle, as illustrated in Figure 2a. It must be stressed that periods of trench advance can occur at the center of the slab while slab edges are retreating (Figure $2 \mathrm{~b}$, time t2).

In this experiment, it is interesting to note that the geometry of the buckled subducting slab evolves within a few tens of Myrs: the two bottom pictures show that 25 Myrs separate the symmetric bulge (trench advance episode all along the slab) from its 3D buckled shape, where trench retreat episodes are evidenced at the slab edges. Another important observation is that trench retreat episodes last longer than trench advances. Actually, this would have been surprising if subduction was purely vertical, but the inclination of the slab promotes - through a simple gravity effect - retreat rather than advance.

\subsection{Convergence rate}

In subducting convergent margins, relative velocities are controlled by several factors, such as the absolute plate velocities, that are in turn strongly coupled to the underlying mantle flow (e.g. Jolivet et al., 2009), trench migration and internal back-arc deformation. Different plate or margin velocities can then be defined (e.g. Heuret and Lallemand, 2005), but they can cover different meanings, depending on what is measured and what is the reference. To clarify this point, we define below the notions of convergence rate and surface subduction rate in trench-orthogonal convergence (Figure 3). These definitions are consistent with those implemented in the paleographic tool used in this study (PaleoGIS ${ }^{\mathrm{TM}}$ ). Additional details can be found in Bertrand (2011) and in Appendix 1.

To simplify, all velocities are considered horizontal and perpendicular to the subduction trench. Considering an oceanic plate $\mathrm{A}$ being subducted beneath an upper plate $\mathrm{B}, \mathrm{Va}$ and $\mathrm{Vb}$ are the absolute velocities of plates $A$ and $B$, respectively. $V t$ is the velocity of the subduction trench migration (or leading edge of the upper plate). In the case of a totally rigid plate $B$, we have:

$$
\mathrm{Vb}=\mathrm{Vt}
$$

As back-arc internal deformation may occur, Ve is the extensional rate within the upper plate. In other words, $\mathrm{Ve}$ is the velocity of the upper plate relative to its leading edge along the subduction trench. We then have: 
$\mathrm{Ve}=\mathrm{Vb}-\mathrm{Vt}$

The convergence rate $V_{c}$ is the velocity of plate $A$ relative to plate $B$, or:

$\mathrm{Vc}=\mathrm{Va}-\mathrm{Vb}$

or

$\mathrm{Vc}=\mathrm{Va}-\mathrm{Vt}-\mathrm{Ve}$

The surface subduction rate Vs, or velocity of the oceanic plate relative to the subduction zone, is the velocity of plate $A$ relative to the leading edge of plate $B$, or:

$\mathrm{Vs}=\mathrm{Va}-\mathrm{Vt}$

Note that the convergence rate may also be written as the difference between the surface subduction rate $\mathrm{Vs}$ and the extensional rate:

$\mathrm{Vc}=\mathrm{Vs}-\mathrm{Ve}$

In section 3 and 4 , the convergence rate as defined above, will be used through a paleotectonic approach, where plates are considered as non-deformable at the surface, meaning, at first order, that $\mathrm{V} c=\mathrm{Vs}$. Note that, to simplify, all velocities above are considered horizontal and perpendicular to the subduction trench, while plate velocities calculated in the following sections correspond to relative convergence rates between plates and thus include an oblique component.

\section{3 - Paleotectonic reconstructions of the western Tethyan region}

\section{1 - The western Tethyan subduction zone}

The present Tethyan suture was built through accretion of micro continents and arcs during convergence between the Africa, India and Eurasia plates, which progressively closed the Tethyan Ocean. This accretionary system extends over $5,000 \mathrm{~km}$ between the collisional fronts of Apulia, to the west, and the Himalayan collision to the east. Numerous studies propose tectonic reconstructions that describe the Mesozoic-Cenozoic evolution of the Tethyan region, such as geodynamic models from Dercourt et al. (1993, 2000), Sengör and Natalin (1996), Stampfli and Borel (2002, 2004), or Golonka (2004). The Tethyan Ocean, which separated Eurasia from India and Africa-Arabia continents, began to close about $180 \mathrm{Ma}$. Continental rifting phases, continental collisions and back-arc spreading episodes have complicated the subduction history of this area. Loiselet et al. (2010a) reconstructed the subduction history using the global P wave model of Li et al. (2008) and the kinematic model of van Hinsbergen et al. (2005). According to these 
geodynamic interpretations of tomographic studies, subduction history of the Tethyan lithosphere began with a relatively straight and wide subducting slab, corresponding to the sinking of the Meso-Tethys lithosphere. Then, after collision of crustal blocks, distinct stages would have involved ridge subduction, slab breakoff and other possible processes (Wortel and Spakman, 2000; Hafkenscheid et al., 2006; Lee et al., 2009). The preferred model by Hafkenscheid et al. (2006) comprises the opening of large back-arc oceanic basins within the Eurasian margin.

Today, after disappearance of almost all the Tethyan lithosphere, some remnants are presently subducting at the Makran, Cyprus, Hellenic and Calabria subduction zones (Figure 1a). While the Makran slab does not seem to advance or retreat (Schellart et al., 2007), the three other slabs show a complicated kinematic history with significant rollback velocities for the Hellenic and Calabria slabs (2.3 and $6.8 \mathrm{~cm} / \mathrm{yr}$, respectively). In addition, the Hellenic slab appears to retreat with a southward increase in velocity, which could be due to a clockwise rotation involving a slab tearing at depth (Brun and Sokoutis, 2010). Note that Figure 1a does not illustrate such local variations in trench velocity. Velocities in Figure 1 correspond to plate velocities with respect to the Indo-Atlantic hotspot reference frame from O'Neill et al. (2005), and consequently differ from values of convergence rates as defined above.

To summarize, subduction of the Tethyan lithosphere probably occurred from middle Jurassic to Upper Cretaceous, along an essentially wide and straight slab, with no or small retrograde (rollback) motion, as suggested by tomographic images (Li et al., 2008). Then, in the last 60 Myrs, tomography data suggest the involvement of a series of smaller curved and retreating subducted slabs.

\section{2 - Distribution of Tethyan porphyry copper deposits}

A large number of porphyry $\mathrm{Cu}$ deposits have been reported along the western Tethyan suture, or Tethyan Eurasian metallogenic belt, especially in southeastern Europe (e.g. Sillitoe, 1980; Singer et al., 2005). In order to study their spatial and temporal distribution, we have compiled a list based on data extracted from (by decreasing order of contribution): 1) the ProMine Mineral Deposits database (Cassard et al., 2012), 2) the "Caucasus Mineral Deposits" database of the BRGM (unpublished data) and 3) the "Porphyry copper deposits of the World" database of the USGS (Singer et al., 2008). The data has been completed, especially for ages of mineralization, by additional published data (Serafimovski, 1999; Volkov et al., 2008; Voudouris et al., 2009; Yigit, 2009). Our dataset contains 238 deposits of porphyry type with their location, ages of mineralization and host rock type and, whenever available, their morphology, status and economic class. From this compilation, we have extracted the 115 deposits, of Creatceous age or younger, which belong to the Tethyan suture. Among these 115 deposits, 80 are of porphyry $\mathrm{Cu} \pm \mathrm{Au} \pm \mathrm{Mo}$ type and 35 are Cu-bearing porphyries of unspecified type. Table 1 provides a brief synthesis of these deposits with their country, name, latitude and longitude coordinates (geographic WGS84, 
decimal degrees), class (based on total Cu potential) and age of mineralization (either absolute age or median age of the stratigraphic series or stage it belongs to). These deposits are distributed along the Tethyan suture from longitude $18^{\circ} \mathrm{E}$ to $66^{\circ} \mathrm{E}$ and range in age from 4.0 (Zanclean, lower Pliocene) to $143.5 \mathrm{Ma}$ (Berriasian, lower Cretaceous).

The spatial and temporal distribution of these deposits is not random. On the contrary, it shows concentrations of deposits along specific segments of the western Tethyan suture and during distinct time periods. In Figure 4, we plot both their ages versus their longitude, and their geographic distribution with age-based symbology. It shows that the occurrence of 110 out of the 115 deposits is organized in five distinct spatial and temporal "clusters" (or groups of neighboring deposits separated from others by significant spatial and/or temporal gaps), that are from the oldest to the youngest:

1. "Older" deposits of the Caucasus area (Armenia, Azerbaijan), lower Cretaceous (5 deposits);

2. Balkan-Carpathian area deposits (Bulgaria, Serbia, Romania), upper Cretaceous and Paleocene (29 deposits);

3. Eastern Turkey-Caucasus area deposits (Georgia, Armenia, Azerbaijan, Western Iran), Eocene (11 deposits);

4. Aegean-Balkan-Carpathian area deposits (Aegean Sea, Greece, Macedonia, Serbia, Romania, Slovakia), Oligocene and Miocene (46 deposits);

5. Middle-East area deposits (Iran, Afghanistan, Pakistan), Miocene (19 deposits).

Because clusters 1,3 and 5 are too poorly sampled $(5,11$ and 19 deposits, respectively, versus 29 and 46 for clusters 2 and 4, respectively) and poorly grouped (i.e. they show significant internal gaps between some neighboring deposits), and because the kinematics through time relative to Eurasia is much better constrained for Africa than Arabia or Iran, we have focused the present study on clusters 2 and 4 . To better understand their formation, we have replaced them in the geodynamic and kinematic contexts that prevailed at the time of their geneses.

\section{3 - Paleotectonic context of Tethyan porphyry copper deposits genesis}

In order to understand the relationships between geodynamic context and the formation of porphyry $\mathrm{Cu}$ deposits in southeastern Europe during upper Cretaceous and Cenozoic (clusters 2 and 4 here above), we have performed paleotectonic reconstructions of the western Tethyan closure. In these reconstructions, Eurasia is the reference - or "anchored" - plate, considered as not moving. Instantaneous velocity fields were included $\left(2.5^{\circ}\right.$ resolution grid) in order to better image the relative displacements of tectonic plates. These reconstructions were made with the PaleoGISTM software (www.paleogis.com), using the UTIG PLATES global kinematic model developed by the Institute for Geophysics at the University of Texas at Austin (e.g. Ghidella et al., 
2007; see Appendix 1).

These paleotectonic reconstructions show interesting geodynamic features that appear to be linked with the formation of porphyry Cu deposits in the Aegean-Balkan-Carpathian region (clusters 2 and 4). We present in Figure 5 four selected reconstructions (Turonian, Selandian, Rupelian and Langhian) that illustrate this point:

- In Turonian (90 Ma, Figure 5a), the NeoTethys Ocean is still spreading while the Vardar Ocean is being subducted beneath Eurasia with a relatively fast convergence rate;

- In Selandian (60 Ma, Figure 5a), the spreading of the NeoTethys comes to an end; the northward migration of Africa had triggered the subduction of the Pindos Ocean beneath Eurasia and the accretion of the Menderes block, resulting in a slowing down of the convergence rate and a segmentation of the subduction; cluster 2 of porphyry $\mathrm{Cu}$ deposits forms during this period;

- In Rupelian (30 Ma, Figure 5b), after the complete closure of the Pindos Ocean, the subduction zone migrates to the south, after an acceleration of the convergence rate during Ypresian-Lutetian times (50-42 Ma);

- In Langhian (15 Ma, Figure 5b), the subduction zone keeps migrating southward; the Arabian plate collides with Eurasia, causing a significant decrease of the convergence rate; cluster 4 of porphyry Cu deposits forms during this period.

These schematic paleotectonic reconstructions show that porphyry $\mathrm{Cu}$ deposits of the Aegean-Balkan-Carpathian area formed during periods of slowing down of the Africa-Eurasia convergence rate in response to accretional or collisional geodynamic events. This suggests a strong control of the convergence kinematics on the occurrence of porphyry deposits. To test this hypothesis, we have plotted the velocity of Africa relative to Eurasia (coordinate $33^{\circ} \mathrm{N}$ and $19^{\circ} \mathrm{E}$ on the northern border of the plate, arbitrarily chosen to best represent the regional plate convergence rate) versus time during Cretaceous and Cenozoic. In addition to the UTIG PLATES model, we have also used the EarthByte global kinematic model, developed at the University of Sydney (e.g. Müller et al., 1997, 2008). The diagram (Figure 6) shows that both kinematic models show similar trends. In addition, it shows that clusters 2 and 4 were emplaced in specific and similar kinematic contexts. This context is characterized by: 1) a relatively high rate of convergence (approximately 3.5 and $2.0 \mathrm{~cm} / \mathrm{yr}$ for cluster 2 and 4, respectively), followed by 2) a drastic decrease of the convergence rate (down to approximately 1.0 and $0.5 \mathrm{~cm} / \mathrm{yr}$ for cluster 2 and 4 , respectively) over time periods of 30-40 Myrs separated by 10 Myrs.

These observations show that variations in the convergence rate between Africa and Eurasia appears to play a key role in the formation of porphyry $\mathrm{Cu}$ deposits. To confirm this, we have tested whether the observation may be reproduced in another subduction zone mineralized with porphyry $\mathrm{Cu}$ deposits, and with a greatly different $3 \mathrm{D}$ evolution. For that, we have chosen the 


\section{4 - Paleotectonic reconstructions of the Andean region}

\section{1 - The Andean subduction zone}

The Andean margin results from the eastward subduction of the Nazca plate beneath South America, at convergence rates that amount to several $\mathrm{cm} / \mathrm{yr}$ but are not constant through time (Pardo-Casas and Molnar, 1987). According to seismic tomography signatures (e.g. Engdahl et al., 1995; Liu et al. 2003), subduction history and geometry of the Andean subduction zone seem much simpler than those of the Tethyan subduction zone. The varying subduction angle (from flat subduction zones in central Peru and northern Chile, to inclined subduction zone beneath Bolivia) was first attributed to slab tears, but Cahill and Isacks (1992) suggested that slab flexures were more appropriate to explain earthquake location and focal mechanism solutions. At depth, the Nazca slab penetrates the lower mantle beneath central South America, but it would be deflected in the southern zone (Engdahl et al., 1995). Recently, Contenti et al. (2012) suggested that beneath Peru and Brazil, the Nazca slab would also undergo significant deformation around the mantle transition zone, and that the absence of reflectivity at $410 \mathrm{~km}$ depth in the back-arc area suggests structural complexities of the subducting plate.

Kinematic features related to convergence rates between the Nazca plate and South America (Figure 1b) are not well understood since new models are still being proposed: Quinteros and Sobolev (2013) suggested that slab penetration into the lower mantle was the main cause explaining the decrease of the convergence rate from 20-25 Ma in northern Chile. However, variations of subduction velocity along the Andean subduction zone (blue numbers in Figure 1b) were also attributed to varying angles of subduction, which could increase or decrease the upperlower plate coupling (Martinod et al., 2010). Note, however, that trench advances in the central part of the Andean subduction zone (positive values of red numbers) where subduction velocity is high, whereas it retreats where subduction velocities are low (Colombia and south Chile).

\section{2 - Distribution of Andean porphyry copper deposits}

Porphyry $\mathrm{Cu}$ deposits in the Andes have been the topic of numerous studies, from margin- to deposit-scale (e.g. Sillitoe, 1977, 1986, 1988; Sillitoe et al., 1982; Petersen and Vidal, 1996; Noble and McKee, 1999; Kay and Mpodosis, 2001; Richards et al., 2001; Masterman et al., 2005; Gow and Walshe, 2005; Hollings et al., 2005; Schütte et al., 2011). Similarly to the western Tethyan suture, we have compiled a list of porphyry $\mathrm{Cu}$ deposits along the Andean subduction. This compilation is based on data extracted from (by order of decreasing contribution): 1) the "Porphyry copper deposits of the World" database of the USGS (Singer et al., 2008) and 2) the "Andes" 
database of the BRGM (e.g. Billa et al., 2004). It contains 155 deposits of porphyry Cu type. Table 2 provides a synthesis of these deposits with their country, name, latitude and longitude coordinates (geographic WGS84, decimal degrees), class (based on total Cu potential) and age of mineralization (either absolute age or median age of the stratigraphic series or stage it belongs to). These deposits are distributed along the Andean subduction, from latitude $9^{\circ} \mathrm{N}$ to $45^{\circ} \mathrm{S}$ and range in age from 4.7 (Zanclean, lower Pliocene) to 291.5 Ma (Cisuralian, lower Permian).

As observed along the western Tethyan suture, the spatial and temporal distribution of the porphyry $\mathrm{Cu}$ deposits along the Andean subduction is not random. It shows, at least for Cenozoic deposits (118 out of the 155), concentrations along specific segments of the subduction zone and during distinct time periods. In Figure 7, we plot both their ages versus their longitude, and their geographic distribution with age-based symbology. It shows that the occurrence of deposits is organized in three distinct spatial and temporal "clusters" (or groups of neighboring deposits separated from others by significant spatial and/or temporal gaps), that are from the oldest to the youngest:

1. Paleocene to lower Eocene (Danian to Ypresian) deposits of the central Cordillera (16 deposits);

2. Upper Eocene to lower Oligocene (Bartonian to Rupelian) deposits of the central Cordillera (36 deposits);

3. Miocene deposits of the central and northern Cordillera (66 deposits);

These clusters fit, at least temporally, with those previously identified by Singer et al. (2005). One could argue that cluster 3 may be divided into several smaller groups. There is, for instance, a clear spatial gap of deposits in southern Peru during Miocene (see orange dots in Figure 7). Also, the identification of only three clusters may seem insufficient when some authors have described more numerous and detailed porphyry $\mathrm{Cu}$ belts along the Andes (e.g. Sillitoe and Perello, 2005). But the important point here is that the emplacement of porphyry $\mathrm{Cu}$ deposits along the Andean subduction, as evidenced here above in the Aegean-Balkan-Carpathian region, is not continuous throughout time, but occurs in discontinuous "pulses" that, we believe, may be linked to the plate kinematics and subduction dynamics.

\section{3 - Paleotectonic context of Andean porphyry copper deposits}

As presented previously for the Africa-Eurasia convergence in the Aegean-Balkan-Carpathian region, we have plotted the velocity of the Nazca plate relative to South America (arbitrary coordinate $20^{\circ} \mathrm{S}$ and $72^{\circ} \mathrm{W}$, on the eastern border of the plate), using the UTIG PLATES and the EarthByte global kinematic models. Because the kinematics of the Nazca plate relative to South America is poorly constrained prior to Eocene, and because cluster 3 is rather poorly sampled (16 deposits, versus 36 and 66 for clusters 2 and 3, respectively), we have focused our study on 
clusters 2 and 3. As done previously in the western Tethyan context, we have replaced these two clusters in their paleokinematic context. The diagram (Figure 8) shows that both clusters were emplaced in a kinematic context that is characterized by a relatively high rate of plate convergence (approximately 10 to 17 and $14 \mathrm{~cm} / y$ r for cluster 2 and 3, respectively) shortly followed by a drastic decrease of this rate (down to approximately 7 to 8 and $11 \mathrm{~cm} / \mathrm{yr}$ for cluster 2 and 3 , respectively) over time periods of $\sim 15$ Myrs separated by 5-10 Myrs. Although the absolute velocities are different, this kinematic context (high then decreasing convergence rate) is very similar to the one in which upper Cretaceous-Paleocene and Oligo-Miocene deposits were emplaced along the western Tethyan suture in the Aegean-Balkan-Carpathian region.

\section{5 - Discussion}

The present study shows that four Cretaceous or younger clusters of porphyry $\mathrm{Cu}$ deposits along the western Tethyan and Andean margins were emplaced in relatively similar kinematic contexts. To explain the observations presented above, we propose a simple geodynamic model, based on the impact of the plate convergence rate on the melting processes and stress regimes that would favor the formation of porphyry $\mathrm{Cu}$ deposits. This model is thus composed of two phases:

1) a high rate of convergence, which could have favored a higher melt production in the mantle wedge (e.g. Tatsumi and Eggins, 1995) and the subsequent formation of magmatic bodies in the lithosphere; followed by

2) a subsequent decrease of the convergence rate, which may be related to a decrease of plate velocity and/or possibly associated with a trench retreat episode (e.g. Schellart, 2005), and would have favored an extensional regime - or at least relaxation of compressional stress - in the upper plate and easier upward ascension of fertile magmas in the crust (Tosdal and Richards, 2001).

As defined in section 2.3 and in Figure 3, the convergence rate $\mathrm{Vc}$ can be written as $\mathrm{Va}-\mathrm{Vb}$ or Va-Vt-Ve. Variations in convergence rates can thus be achieved by variations in the three velocities $\mathrm{Va}, \mathrm{Vt}$ and $\mathrm{Ve}$. While plate kinematics may induce increases or decreases in the absolute plate velocities $(\mathrm{Va})$, trench velocity $(\mathrm{Vt})$ and extensional rate $(\mathrm{Ve})$, these are intimately linked to the temporal evolution of slab dynamics in the upper mantle. In the following sections, we focus our interpretation and discussion on the effects of plate kinematics, controlling variations in $\mathrm{Va}$, and on the effects of slab dynamics, controlling variations in $\mathrm{Vt}$ and $\mathrm{Ve}$.

\subsection{Plate kinematics}


The correlation between convergence rate and melt production in the mantle wedge, which has been suggested by Tatsumi and Eggins (1995), has been confirmed by more recent studies. For instance, numerical models from Cagnioncle et al. (2007) and geochemical studies from Huang and Lundstrum (2007) confirm that melt production increases with increasing convergence rate. To support the second point, analog and numerical models by Faccenna et al. (1996) and Becker et al. (1999) showed that a decreasing convergence rate can lead to slab retreat and extensional regimes in the upper plate, which could, in turn, ease ascension of fertile magmas stocked at the base of the lower crust (Tosdal and Richards, 2001; Richards, 2003, 2005). Numerical models of subduction by Capitanio et al. (2010a) show that the reduction of the AfricaEurasia convergence along the Hellenic subduction (as proposed by Jolivet and Faccenna, 2000) below the rate allowed by the slab's own buoyancy could explain the forced trench migration, rollback and stretching within the upper plate. Another recent study, by Jolivet et al. (2009), on the Mediterranean subduction zones shows that flow lines in the mantle are parallel to stretching directions in metamorphic core complexes. They deduce that slab retreat drives a significant part of extensional crustal deformation in the upper plate. In addition, regional tectonic studies show that emplacements of clusters 2 and 4 in the Aegean-Balkan-Carpathian region coincide, spatially and temporally, with extensional regimes that affect, respectively, the Moesian Platform in upper Cretaceous, and the Aegean-Balkan area in Oligo-Miocene (e.g. Jolivet and Faccenna, 2000; Jolivet and Brun, 2010). However, if collision and accretion of blocks, as shown on paleotectonic reconstructions above (Figure 5) and trench migration could partly explain the upper Cretaceous and Cenozoic evolution of the Africa-Eurasia subduction dynamics, such processes could hardly be proposed in the context of the Andean Subduction.

The age and thermal profile of the subducting plate has a strong impact on the velocity and dip of the downgoing slab (Uyeda and Kanamori, 1979). This may generate considerable differences from one subduction zone to another, but the age gradient within the subducting plate could also significantly modify the dynamics of subduction. For instance, the surges in the Nazca-south America convergence rate observed approximately 45-40 Ma and $20 \mathrm{Ma}$ (Pardo-Casas and Molnar, 1987; Sdrolias and Müller, 2006; and Figure 8) could be explained by strong along-trench age gradients increasing the driving force of the slab (Capitanio et al., 2011). In addition, Jordan et al. (1983) described graben-like (i.e. extensional or transtensional) structures along the Andean forearc (Longitudinal Valley in northern Chile and Central Valley in central Chile) that developed above segments of steeply dipping $\left(\sim 30^{\circ}\right)$ Benioff zones. As a consequence, the succession of fast then decreasing convergence rates that is associated with the emplacement of upper Eocenelower Oligocene and Miocene porphyry $\mathrm{Cu}$ deposit clusters along the Andean margin may be explained by: 1) the subduction of older (i.e. less buoyant) portions of the Nazca oceanic crust and 2) the delayed response of the slab and the possible resulting relaxation of the compressional stress in the upper plate. This scenario, however, would need to be confirmed by further investigations. 
Another aspect that may impact plate kinematics and the stress regime in the upper plate is the presence of asperities on the subducting plate. A synthesis by Cooke et al. (2005) shows that the formation of large Neogene porphyry Cu deposits in the circum-Pacific region has been closely associated with subduction of ridges, seamount chains or oceanic plateaus beneath island and continental arcs. In Chile, subduction of the Juan Fernández ridge migrated along nearly 1,400 km of the margin during Miocene (Yáñez et al., 2001). Subduction of this ridge is considered by Hollings et al. (2005) to be a key geodynamic process responsible for the genesis of several giant porphyry $\mathrm{Cu}$ deposits by favoring crustal scale faulting and possibly acting as a source of metals. In addition, Richards et al. (2001) and Gow and Walshe (2005) have identified preexisting extensional tectonic architectures in Chile that could have favored the formation of large porphyry Cu deposits.

Recently, Rosenbaum et al. (2005) suggested a causal link between the subduction of topographic anomalies (Nazca Ridge and Inca Plateau) and spatial and temporal distribution of ore deposits in Peru during the last 15 Myrs. According to Kay and Mpodozis (2001), hydration and crustal thickening episodes along the Andean subduction zone are associated with "transitions in and out of flat-subduction"; these processes would correspond to major controls on the formation of ore deposits. In other words, the authors emphasized the need to understand how the geometry of the Nazca plate changed with time. Similarly, Billa et al. (2004) pointed out that the amount of mineralization along the Andean subduction zone correlates with small slab dip angles.

\subsection{Slab dynamics}

The discontinuous "pulses" during which porphyry $\mathrm{Cu}$ deposit clusters formed through time appear to be associated with significant variations in convergence rates, thus suggesting a nonsteady-state behavior of the subducting slab. Indeed, as described in section 2, the subducted lithosphere may pile-up on the upper-lower mantle discontinuity forming alternating forward and backward folds. This folding behavior would generate, at the surface, frontward and rearward (respectively) horizontal trench motions and associated compressive and extensional (respectively) stress regimes in the upper plate (Capitanio et al., 2010b).

Assuming that the 3D buckling behavior of the slab (Figure 2) is valid for the Andean subduction zone, one could expect favorable conditions for ore deposition when slab segments retreat (extension phase), while temporal gaps of mineralization could occur during trench advance episodes (compression phase). If the present-day Andean slab shape and porphyry ore deposit distribution are considered, one can see in Figure 7 a significant gap of deposits where trench velocity is positive (trench advances between latitude of $\sim 25^{\circ} \mathrm{S}$ and $15^{\circ} \mathrm{S}$ ), while numerous porphyry $\mathrm{Cu}$ deposits have formed where trench retreats in the last $15 \mathrm{Myrs}$. One could go further in the geodynamic interpretation by inferring that, from Rupelian to Lutetian ( 45 to $30 \mathrm{Ma}$ ), the trench was probably retreating between latitude $30^{\circ} \mathrm{S}$ and $15^{\circ} \mathrm{S}$ as numerous porphyry Cu deposits 
were generated (Figure 7). On the other hand, the spatial gaps, south of $30^{\circ} \mathrm{S}$ and north of $15^{\circ} \mathrm{S}$ might correspond to trench advance episodes in this period. However, one should keep in mind that these inferences may be biased as we do not account here for possible variations in plate velocity, which would also affect the convergence rate.

Applying similar relationships to the Tethyan subduction zone, one may suggest that the two retreating episodes between longitudes $17^{\circ} \mathrm{E}$ and $30^{\circ} \mathrm{E}$ were separated by an advance phase between $\sim 60$ and $45 \mathrm{Ma}$ (see gap of mineralizing events in Figure 4). At longitudes $35^{\circ} \mathrm{E}$ to $45^{\circ} \mathrm{E}$, while the trench was retreating from Paleocene to Oligocene, it was probably advancing at its eastern edge. Such alternating slab motions are in accordance with a lateral buckling behavior at depth.

\subsection{Metallogenic potential}

An interesting pattern appears when temporal distribution of $\mathrm{Cu}$ potential along both subduction zones is studied. Figure 9 illustrates the temporal clusters already discussed in Figures 4 and 7 , together with the amount of potential $\mathrm{Cu}$ and the number of deposits per 10 Myr-period (see Tables 1 and 2). In both cases, a bimodal distribution can be defined. Periods of mineralizing events, which last around 40 Myrs (grey shadings in histograms of Figure 9), appear to be separated by barren phases lasting $\sim 10$ to 20 Myrs. Note that the number of porphyry Cu deposits (indicated on top of each bar) is maximum right before the barren phases, except for the Cretaceous Tethyan ones.

The barren phases could represent kinematic conditions for which tectonic compression prevents upward migration of enriched magmas. During such short-lasting phases, convergence rates are high and trenches are assumed to advance, while mineralizing phases would be associated with decreasing convergence rates, possibly related to trench retreat episodes and associated extension, lasting 40 Myrs. Figures 10 highlights how these processes can be triggered: by a decreasing plate velocity (Figure 10a) and/or a slab buckling process (Figure 10b). One should note that model of Figure 10 is schematic and only considers - for simplification orthogonal convergence. Paleotectonic reconstructions in the present paper include oblique component of convergence that could produce transpressional and/or transtensional tectonic deformation in the upper plate that are important in the formation of porphyry deposits (Tosdal and Richards, 2001). An interesting fact of the buckling phenomenon is that time periods of slab rollback are probably much longer than time periods of trench advance, as illustrated in laboratory experiments, and it turns out that metallogenic data seem to show a similar temporal behavior. Indeed, the recent study by Ouyang et al. (2013) underlines similar time-scales for subductionrelated ore deposits in northeastern China.

Although emplacement of porphyry $\mathrm{Cu}$ deposits in Andean and Tethyan subduction zones 
seems to occur in similar kinematic contexts, Cu potential - in terms of tonnage - is not of the same order (see units of vertical axes in Figure 9). While our database on Andean porphyry $\mathrm{Cu}$ deposits contains 19 ore deposits with a total $\mathrm{Cu}$ potential greater than $10 \mathrm{Mt}$ (including the giant ore deposits of Chuquicamata, El Teniente, Los Bronces, La Escondida), the largest Cu potential of Tethyan porphyry Cu deposits amounts to $8.4 \mathrm{Mt}$ (Sar Cheshmeh, Iran). This difference may be due to the high convergence rates along the Andean subduction zone, which are roughly five times greater than along the Tethyan subduction zone (Figures 6 and 8). Indeed, it seems reasonable to consider that higher subduction velocities would involve higher melt production beneath the upper plate. One should, however, consider these results cautiously as latitudinal and longitudinal distribution of Andean and western Tethyan deposits, respectively, is not considered.

\section{6- Conclusion}

Despite their different geodynamic regions and subduction context, we evidenced four clusters of porphyry $\mathrm{Cu}$ deposits - two of upper Cretaceous-Paleocene and Oligo-Miocene age in the Aegean-Balkan-Carpathian region (closure of the western Tethys), and two of Eocene-lower Oligocene and Miocene age along the Andes (subduction of the Nazca plate) - that were emplaced in relatively similar kinematic contexts. These contexts are characterized by: 1) a relatively fast convergence rate that could have favored higher melt production in the mantle wedge, followed by 2) a drastic decrease of the convergence rate that may have favored extensional regime and/or relaxation of compressional stress in the upper plate and easier ascension of fertile magmas to the upper crust. We suggest that this polyphased kinematic context, which can be explained by plate kinematics, may also be linked to a slab buckling process.

In addition, the present study based on a paleotectonic approach confirms the control of the geodynamic context, and especially subduction dynamics, on the genesis of porphyry Cu deposits. Further development of this work will aim to consider the magmatism associated with the deposits, in order to confirm the link between deep mantle processes and their genesis in the upper crust (see for instance the work from Pe-Piper and Piper (2006, 2007) on backarc volcanism in the Aegean Sea). One way to validate our general approach would consist in studying additional convergent margins. Nevertheless, the present study confirms that the paleotectonic approach is a promising tool that could help identify geodynamic and tectonic criteria favoring the genesis of several mineral deposit types. As a corollary, spatial and temporal concentrations of porphyry $\mathrm{Cu}$ deposits may be seen as possible indicators of rapid then decreasing subduction rates in the past. More generally, mineral deposits, according to their type, may be seen as interesting markers of past geodynamic contexts (e.g. Pirajno, 2004; Bierlein et al. 2006; Guillou-Frottier et al. 2012). We believe that the approach presented in this study could be applied to all subduction zones hosting porphyry $\mathrm{Cu}$ ore deposits, in order to better constrain their kinematic history. 


\section{Acknowledgements}

This study was done within the framework of the scientific research activity at BRGM and was fully funded by its Research Division. We wish to thank our colleagues Laurent Bailly, Daniel Cassard, Laurent Jolivet and Armel Menant, whose discussions and remarks helped improve this work. We also wish to warmly thank Jeremy P. Richards, whose constructive review and comments also greatly helped improve this work. We thank our colleague John Douglas for improving the English in our manuscript (we are fully responsible for all remaining errors). We also wish to thank participants to the workshop "Mineral Resources Potential Maps: A Tool for Discovering Future Deposits" (12th-14th March 2012, Nancy, France), where preliminary results of this work were presented and discussed, for their highly constructive comments. We also thank Saadeddine Benhammouda, from the BRGM's IT Department, and Doug Harris, from The Rothwell Group L.P., for their help in learning and using PaleoGIS ${ }^{\mathrm{TM}}$.

\section{References}

Barley ME, Krapez B., Groves DI, Kerrich R, 1998. The late Archean bonanza: metallogenic and environmental consequences of the interaction between mantle plumes, lithosphere tectonics and global cyclicity. Precamb. Res. 91, 65-90

Becker TW, Faccenna C, O'Connell R, Giardini D, 1999. The development of slabs in the upper mantle: Insights from numerical and laboratory experiments. J. Geophys. Res. 104, 15,20715,226

Bertrand G, 2011. Reconstructions paléogéographiques: un nouveau domaine de recherché au service de la prédictivité des ressources minérales au BRGM. BRGM report RP-60651-FR, 65 p., 40 Fig., 1 Appendix, in French

Berzina AN, Sotnikov VI, Economou-Eliopoulos M, Eliopoulos DG, 2005. Distribution of rhenium in molybdenite from porphyry Cu-Mo and Mo-Cu deposits of Russia (Siberia) and Mongolia. Ore Geol. Rev. 26, 91-113

Bierlein FP, Groves DI, Goldfarb RJ, Dubé B, 2006. Lithospheric controls on the formation of provinces hosting giant orogenic gold deposits. Miner. Deposita, 40, 874-886

Billa M, Cassard D, Lips, ALW, Bouchot V, Tourlière B, Stein G, Guillou-Frottier L, 2004. Predicting gold-rich epithermal and porphyry systems in the central Andes with a continental-scale metallogenic GIS. Ore Geol. Rev. 25, 39-67 
Billen MI, 2008. Modelling the dynamics of subducting slabs, Annu. Rev. Earth Planet. Sci., 36, 325-356

Brun JP, Sokoutis D, 2010. 45 m.y. of Aegean crust and mantle flow driven by trench retreat. Geology, 38, 815-818

Burnham, C.W., 1979. Magmas and hydrothermal fluids, in Barnes, H.L., ed., Geochemistry of hydrothermal ore deposits, 2nd edition: New York, John Wiley and Sons, p. 71-136

Butterworth NP, Talsma AS, Müller RD, Seton M, Bunge HP, Schubert BSA, Shephard GE, Heine C, 2014. Geological, tomographic, kinematic and geodynamic constraints on the dynamics of sinking slabs. J. Geodyn., 73, 1-13

Cagnioncle AM, Parmentier EM, Elkins-Tanton L, 2007. Effect of solid flow above a subducting slab on water distribution and melting at convergent plate boundaries. J. Geophys. Res. 112, B09402, doi:10.1029/2007JB004934

Cahill T, Isacks BL, 1992. Seismicity and shape of the subducted Nazca plate. J. Geophys. Res., 97, 17,503-17,529. Capitanio F.A., Faccenna C., Zlotnik S. and Stegman D.R., 2011. Subduction dynamics and the origin of the Andean orogeny and the Bolivian orocline. Nature 480, 83-86

Capitanio FA, Zlotnik S, Faccenna C, 2010a. Controls on subduction reorganization in the Hellenic margin, eastern Mediterranean. Geophys. Res. Lett. 37, Doi:10.1029/2010GL044054

Capitanio FA, Stegman DR, Moresi LN, Sharples W, 2010b. Upper mantle control on deep subduction, trench migrations and deformations at convergent margins. Tectonophysics, 483, 80-92

Capitanio FA, Faccenna C, Zlotnik S, Stegman DR, 2011. Subduction dynamics and the origin of Andean orogeny and the Bolivian orocline. Nature, 480, 83-86

Carranza EJM, 2011. Geocomputation of mineral exploration targets. Computers \& Geosciences, 37, 1907-1916

Cassard D, Billa M, Lambert A, Picot JC, Husson Y, Lasserre JL, Delor C, 2008. Gold predictivity mapping in French Guiana using an expert-guided data-driven approach based on a regionalscale GIS. Ore Geol. Rev. 34, 471-500

Cassard D, Bertrand G, Maldan F, Gaàl G, Juha K, Aatos S, Angel JM, Arvanitidis N, Ballas D, Billa M, Christidis C, Dimitrova D, Eilu P, Filipe A, Grazea E, Inverno C, Kauniskangas E, Maki T, Matos J, Meliani M, Michael C, Mladenova V, Navas J, Niedbal M, Perantonis G, Pyra J, 
Santana H, Serafimovski T, Serrano JJ, Strengel J, Tasev G, Tornos F, Tudor G, 2012. ProMine pan-European Mineral Deposit database: a new dataset for assessing primary mineral resources in Europe. Mineral Resources Potential Maps: a Tool for Discovering Future Deposits. 12th-14th March 2012, Nancy, France

Christensen UR, 1996. The influence of trench migration on slab penetration into the lower mantle. Earth Planet. Sci. Lett., 140, 27-39

Cline, J.S., and Bodnar, R.J., 1991. Can economic porphyry copper mineralization be generated by a typical calc-alkaline melt? Journal of Geophysical Research, v. 96, p. 8113-8126

Cloos, M., 2001. Bubbling magma chambers, cupolas, and porphyry copper deposits: International Geology Review, v. 43, p. 285-311

Contenti S, Gu YJ, Okeler A, Sacchi MD, 2012. Shear wave reflectivity imaging of the Nazca-South America subduction zone: stagnant slab in the mantle transition zone? Geophys. Res. Lett., 39, L02310, doi:10.1029/2011GL050064

Cooke DR, Hollings P, Walshe JL, 2005. Giant porphyry deposits: characteristics, distribution and tectonic controls. Econ. Geol. 100, 801-818

De Boorder H, Spakman W, White SH, Wortel MJR, 1998. Late Cenozoic mineralization, orogenic collapse and slab detachment in the European Alpine belt, Earth Planet. Sci. Lett., 164, 569-575

Dercourt J, Ricou LE, Vrielynck B (Eds.), 1993. Atlas Tethys Paleoenvironmental Maps. GauthierVillars, Paris

Dercourt J, Gaetani M, Vrielynck B, Barrier E, Biju-Duval B, Brunet MF, Cadet JP, Crasquin S, Sandulescu M (Eds.), 2000. Atlas Peri-Tethys Paleoegeographical Maps, vol. I-XX. CCGM/CGMW, Paris, pp. 1 - 269. 24 maps and explanatory note

Di Giuseppe E, van Hunen J, Funiciello F, Faccenna C, Giardini D, 2008. Slab stiffness control of trench motion: insights from numerical models. Geochem. Geophys. Geosys., 9, Q0214, doi :10.1029/2007GC001776

Dvorkin J., Nur A, Mavko G, Benavraham Z, 1993. Narrow subducting slabs and the origin of backarc basins. Tectonophys., 227, 63-79

Engdahl ER, van der Hilst RD, Berrocal J, 1995. Imaging of subducted lithosphere beneath South America. Geophys. Res. Lett. , 22, 2317-2320

Faccenna C, Davy P, Brun J, Funiciello R, Giardini D, Mattei M, Nalpas, T., 1996. The dynamics of back-arc extension; an experimental approach to the opening of the tyrrhenian sea. Geophys. J. 
Int. 126(3), 781-795

Faccenna C, Heuret A, Funiciello F, Lallemand S, Becker TW, 2007. Predicting trench and plate motion from the dynamics of a strong slab. Earth Planet. Sci. Lett. 257, 29-36

Funiciello F, Moroni M, Piromallo C, Faccenna C, Cenedese A, Bui HA, 2006. Mapping mantle flow during retreating subduction: laboratory models analyzed by feature tracking, J. Geophys. Res., 111, B03402, doi:10.1029/2005JB003792

Fukao Y, Obayashi M, Inoue H, Nenbai M, 1992. Subducting slabs stagnant in the transition zone, J. Geophys. Res., 97, 4809-4822

Ghidella ME, Lawver LA, Gahagan LM, 2007. Break-up of Gondwana and opening of the South Atlantic: Review of existing plate tectonic models, U.S. Geological Survey and The National Academies: USGS OF-2007-1047, Short Research Paper 055, doi:10.3133/of2007-1047.srp055

Goes S, Capitanio FA, Morra G, 2008. Evidence of lower-mantle slab penetration phases in plate motions, Nature, 451, 981-984

Golonka J, 2004. Plate tectonic evolution of the southern margin of Eurasia in the Mesozoic and Cenozoic. Tectonophysics 381, 235-273

Gow PA, Walshe JL, 2005. The role of preexisting geologic architecture in the formation of giant porphyry-related $\mathrm{Cu} \pm \mathrm{Au}$ deposits: examples from New Guinea and Chile. Econ. Geol. 100, 819-833

Griffiths RW, Hackney RI, van der Hilst RD, 1995. A laboratory investigation of effects of trench migration on the descent of subducted slabs. Earth Planet. Sci. Lett., 133, 1-17

Guillou-Frottier L, Buttles J, Olson P, 1995. Laboratory experiments on the structure of subducted lithosphere. Earth Planet. Sc. Lett. 133, 19-34

Guillou-Frottier L, Burov E, 2003. The development and fractuting of plutonic apexes : implications for porphyry ore deposits. Earth Planet. Sci. Lett., 214, 341-356

Guillou-Frottier L, Burov E, Cloetingh S, Le Goff E, Deschamps Y, Huet B, Bouchot V, 2012. Plume-induced dynamic instabilities near cratonic blocks: implications for P-T-t paths and metallogeny. Global Planet. Ch. 90-91, 37-50

Hafkenscheid E, Wortel MJR, Spakman W, 2006. Subduction history of the Tethyan region derived from seismic tomography and tectonic reconstructions. J. Geophys. Res., 111, B08401, doi:10.1029/2005JB003791 
Hayes GP, Wald DJ, Johnson RL, 2012. Slab1.0: a three-dimensional model of global subduction zone geometries. J. Geophys. Res., 117, B01302, doi:10.1029/2011JB008524

Heuret A, Lallemand S, 2005. Plate motions, slab dynamics and back-arc deformation. Phys. Earth Planet. Int., 149, 31-51

Hollings P, Cooke D, Clark A, 2005. Regional geochemistry of Tertiary igneous rocks in Central Chile: implications for the geodynamic environment of giant porphyry copper and epithermal gold mineralization. Econ. Geol. 100, 887-904

Houseman GA, Gubbins D, 1997. Deformation of subducted lithosphere. Geophys. J. Int., 131, $535-551$

Huang F, Lundstrom CC, 2007. ${ }^{231} \mathrm{~Pa}$ excesses in arc volcanic rocks: constraint on melting rates at convergent margins. Geology, 35, 1007-1010

Husson L, 2012. Trench migration and upper plate strain over a convecting mantle. Phys. Earth Planet. Inter., 212-213, 32-43

Jadamec MA, Billen MI, 2010. Reconciling surface plate motions with rapid three-dimensional mantle flow around a slab edge. Nature, 465, 338-342

Jébrak M, Marcoux E, 2008. Géologie des ressources minérales. Géologie Quebec Ed., 667 p.

Jolivet L, Faccenna C, 2000. Mediterranean extension and the Africa-Eurasia collision. Tectonics $19,1095-1106$

Jolivet L, Faccenna C, Piromallo C, 2009. From mantle to crust: stretching the Mediterranean. Earth Planet. Sci. Lett. 285, 198-209

Jolivet L, Brun JP, 2010. Cenozoic geodynamic evolution of the Aegean. Int. J. Earth Sci. (Geol. Rundsch.), 99, pp. 109-138

Jordan TE, Isacks BL, Allmendinger RW, Brewer JA, Ramos VA, Ando CJ, 1983. Andean tectonics related to geometry of subducted Nazca plate. Geol. Soc. Am. Bull. 94, 341-361

Kay SM, Mpodozis C, 2001. Central Andean ore deposits linked to evolving shallow subduction systems and thickening crust. Geol. Soc. Amer. Today, March 2001, 4-9

Kerrich R, Goldfarb RJ, Richards JP, 2005. Metallogenic Provinces in an Evolving Geodynamic Framework. Econ. Geol. 100 ${ }^{\text {th }}$ Anniversary Volume, 1097-1136

Kincaid C, Olson P, 1987. An experimental study of subduction and slab migration. J. Geophys. 
Lee HY, Chung SL, Lo CH, Ji J, Lee TY, Qian Q, Zhang Q, 2009. Eocene Neotethyan slab breakoff in southern Tibet inferred from the Linzizong volcanic record. Tectonophysics, 477, 2035

Lescuyer JL, Lips ALW, 2004. Gold and Copper distribution of the Alpine-Tethys Belt. In IGC 32nd - International Geological Congress, 20th-28th August 2004, Florence, Italy

Li C., van der Hilst RD, Engdahl R, Burdick S, 2008. A new global model for $P$ wave speed variations in Earth's mantle, Geochem. Geophys. Geosys., 9, 5, doi:10.1029/2007GC001806.

Lips ALW, 2007. Geodynamic causes of copper and gold concentrations in the Tethys belt. Proceedings of the Ninth Biennial SGA Meeting, Dublin 2007, pp. 93-96

Liu, KH, Gao SS, Silver PG, Zhang Y, 2003, Mantle layering across central South America, J. Geophys. Res., 108, 2510, doi:10.1029/2002JB002208

Loiselet C, Husson L, Braun J, 2009. From longitudinal slab curvature to slab rheology, Geology, 37, 747-750, doi :10.1130/G30052A.1

Loiselet C, Guillou-Frottier L, Bertrand G, Billa M, Pelleter E, Maldan F, Cassard D, 2010a. Spatial distribution of mineral deposit along eastern Mediterranean subduction zone: a link with 3D mantle flow associated with slab rollback?, GEOMOD 2010, 27th-29th September 2010, Lisbon, Portugal

Loiselet C., Braun J., Husson L., Le Carlier de Veslud C., Thieulot C., Yamato P., Grujic D., 2010b. Subducting slabs: jellyfishes in the Earth's mantle, Geochem. Geophys. Geosyst., 11, Q08016, doi:10/1029/2010GC003172

Martinod J, Husson L, Roperch P, Guillaume B, Espurt N, 2010. Horizontal subduction zones, convergence velocity and the building of the Andes, Earth Planet. Sci. Lett., 299, 299-309

Masterman GJ, Cooke DR, Berry RF, Walshe JL, Lee AW, Clark AH, 2005. Fluid chemistry, structural setting, and emplacement history of the Rosario Cu-Mo porphyry and Cu-Ag-Au epithermal veins, Collahuasi district, Northern Chile. Econ. Geol. 100, 835-862

Melfos V, Voudouris P, Arikas K, Vavelidis M, 2001. Rhenium-rich molybdenites in Thracian

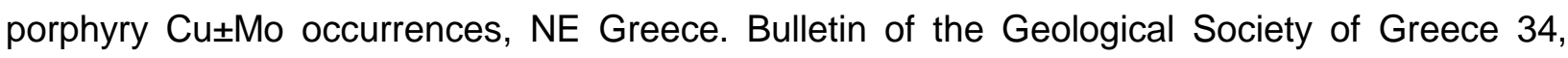
1015-1022

Mitchell AHG, Garson MS, 1981. Mineral deposits and global tectonic settings, New York, Academic Press, 405 p. 
Morra G, Regenauer-Lieb K, Giardini D, 2006. Curvature of oceanic arcs, Geology, 34; 10; 877880

Morra G, Quevedo L, Müller RD, 2012. Spherical dynamic models of top-down tectonics, Geochem. Geophys. Geosys., 13, Q03005, doi:10.1029/2011GC003843

Müller RD, Roest WR, Royer JY, Gahagan LM, Sclater, J.G., 1997. Digital isochrons of the world's ocean floor. J. Geophys. Res. 102, 3211-3214

Müller RD, Sdrolias M, Gaina C, Roest WR, 2008. Age, spreading rates and spreading asymmetry of the world's ocean crust. Geochem. Geophys. Geosyst. 9, Q04006, doi:10.1029/2007GC001743

Myhill R, 2013. Slab buckling and its effect on the distributions and focal mechanisms of deepfocus earthquakes, Geophys. J. Int., 192, 837-853

Neubauer F, Lips A, Kouzmanov K, Lexa J, Ivascanu P, 2005. Subduction, slab detachment and mineralization: the Neogene in the Apuseni Mountains and Carpathians, Ore Geol. Rev., 27, 1344

Noble DC, McKee EH, 1999. The Miocene metallogenic belt of central and northern Peru. Society of Economic Geologists Special Publications 7, 155-193

O'Neill C, Müller D, Steinberger B, 2005. On the uncertainties in hot spot reconstructions and the significance of moving hot spot reference frames, Geochem. Geophys. Geosyst., 6, Q04003, doi:10.1029/2004GC000784

Ouyang HG, Mao JW, Santosh M, Zhou J, Zhou ZH, Wu Y, Hou L, 2013. Geodynamic setting of Mesozoic magmatism in NE China and surrounding regions: perspectives from spatio-temporal distribution patterns of ore deposits, Journal of Asian Earth Sciences (2013), doi: http://dx.doi.org/10.1016/j.jseaes.2013.07.011

Pardo-Casas F, Molnar P, 1987. Relative motion of the Nazca (Farallon) and South American plates since Late Cretaceous time. Tectonics 6, 233-248

Pe-Piper G, Piper DJW, 2006. Unique features of the Cenozoic igneous rocks of Greece, Geol. Soc. Amer. Sp. Pap., 409, 259-282

Pe-Piper G, Piper DJW, 2007. Neogene backarc volcanism of the Aegean: new insights into the relationship between magmatism and tectonics. Geological Society of America Special Paper 418, 17-31

Petersen U, Vidal CE, 1996. Magmatic and tectonic controls on the nature and distribution of 
copper deposits in Peru. Society of Economic Geologists Special Publications 5, 1-18

Pirajno F, 2004. Hotspots and mantle plumes: global intraplate tectonics, magmatism and ore deposits. Mineral. Petrol. 82, 183-216

Quinteros J, Sobolev SV, 2013. Why has the Nazca plate slowed since the Neogene? Geology, $41,31-34$

Ribe NM, Stutzmann E, Ren Y, van der Hilst R, 2007. Buckling instabilities of subducted lithosphere beneath the transition zone, Earth Planet Sci. Lett., 254, 173-179

Ricard Y, Richards M, Lithgow-Bertelloni C, 1993. A geodynamic model of mantle density heterogeneity. J. Geophys. Res., 98, 21,895-21,909

Richards JP, Boyce AJ, Pringle MS, 2001. Geologic evolution of the Escondida area, northern Chile: a model for spatial and temporal localization of porphyry Cu mineralization, Econ. Geol. 96, 271-305

Richards JP, 2003. Tectono-magmatic precursors for porphyry $\mathrm{Cu}$-(Mo-Au) deposit formation. Econ. Geol. 98, 1515-1533

Richards JP, 2005. Cumulative factors in the generation of giant calc-alkaline porphyry $\mathrm{Cu}$ deposits; in Porter T.M. (Ed.), Super porphyry copper and gold deposits: a global perspective, PGC Publishing, Adelaide, v. 1, pp. 7-25

Richards JP, 2011. Magmatic to hydrothermal metal flux in convergent and collided margins. Ore Geol. Rev. 40, 1-26

Rosenbaum G, Giles D, Saxon M, Betts PG, Weinberg RW, Duboz C, 2005. Subduction of the Nazca Ridge and the Inca Plateau: insigths into the formation of ore deposits in Peru. Earth Planet. Sci. Lett., 239, 18-32

Sawkins FJ, 1984. Metal Deposits in Relation to Plate Tectonics, Berlin, Springer, 325 p.

Schellart WP, 2004. Kinematics of subduction and subduction-induced flow in the upper mantle, J. Geophys. Res., 109, B07401, doi:10.1029/2004JB002970

Schellart WP, 2005. Influence of the subducting plate velocity on the geometry of the slab and migration of the subduction hinge. Earth Planet. Sc. Lett. 231, 197-219

Schellart WP, 2010. Evolution of subduction zone curvature and its dependence on the trench velocity and the slab to upper mantle viscosity ratio. J. Geophys. Res., 115, B11406, doi:10.1029/2009JB006643 
Schellart WP, Freeman J, Stegman DR, Moresi L, May D, 2007. Evolution and diversity of subduction zones controlled by slab width. Nature, 446, 308-311

Schellart WP, Stegman DR, Farrington RJ, Moresi L, 2011. Influence of lateral slab edge distance on plate velocity, trench velocity, and subduction partitioning. J. Geophys. Res., 116, B10408, doi:10.1029/2011JB008535

Schettino A, Tassi L, 2012. Trench curvature and deformation of the subducting lithosphere. Geophys. J. Int., 188, 18-34

Schütte $P$, Chiaradia M, Barra F, Villagomez D, Beate B, 2011. Metallogenic features of Miocene porphyry $\mathrm{Cu}$ and porphyry-related mineral deposits in Ecuador revealed by $\mathrm{Re}-\mathrm{Os}, 40 \mathrm{Ar} / 39 \mathrm{Ar}$, and U-Pb geochronology. Miner Deposita, doi: 10.1007/s00126-011-0378-z

Scotese CR, Nokleberg WJ, Monger JWH, Norton IO, Parfenov LM, Khanchuk AI, Bundtzen TK, Dawson KM, Eremin RA, Frolov YF, Fujita K, Goryachev NA, Pozdeev Al, Ratkin VV, Rodionov SM, Rozenblum IS, Scholl DW, Shpikerman VI, Sidorov AA, Stone DB, 2001. Dynamic computer model for the metallogenesis and tectonics of the circum-north Pacific. U.S. Geological Survey Open-File Report 01-261, version 1.0, 7 p.

Sdrolias M, Müller RD, 2006. Controls on back-arc basin formation. Geochem. Geophys. Geosyst. 7, Q04016, DOI 10.1029/2005GC001090

Seedorff E, Dilles JH, Proffett JM Jr., Einaudi MT, Zurcher L, Stavast WJA, Johnson DA, Barton MD, 2005. Porphyry deposits: characteristics and origin of hypogene features. Econ. Geol. 100th Anniversary Volume, 251-298

Sengör AMC, Natalin BA, 1996. Paleotectonics of Asia: fragments of a synthesis. In: Yin, An, Harrison, T.M. (Eds.), The tectonic evolution of Asia. Cambridge Univ. Press, Cambridge, 486640

Serafimovski T, 1999. The Lece-Chalkidiki metallogenic zone: geotectonic setting and metallogenic features. Geologija 42, 159-164

Shinohara, H., and Hedenquist, J.W., 1997, Constraints on magma degassing beneath the Far Southeast porphyry Cu-Au deposit, Philippines: Journal of Petrology, v. 38, p. 1741-1752

Sillitoe $\mathrm{RH}, 1972$. A plate tectonic model for the origin of porphyry copper deposits. Econ. Geol. 67, 184-197

Sillitoe RH, 1977. Permo-Carboniferous, Upper Cretaceous, and Miocene porphyry copper-type mineralization in the Argentinian Andes. Econ. Geol. 72, 99-109 
Sillitoe $\mathrm{RH}, 1980$. The Carpathian-Balkan porphyry copper belt - a Cordilleran perspective. European Copper Deposits International Symposium, Bor, Yugoslavia, 18-22 September 1979, Proceedings, 26-35

Sillitoe $\mathrm{RH}, 1986$. Space-time distribution, crustal setting and $\mathrm{Cu} / \mathrm{Mo}$ ratios of central Andean porphyry copper deposits; metallogenic implications. Special Publication of the Society for Geology Applied to Mineral Deposits, 4, 235-250.

Sillitoe RH, 1988. Epochs of intrusion-related copper mineralization in the Andes. J. South Amer. Earth Sci. 1, 285-311

Sillitoe RH, 2010. Porphyry copper systems. Econ. Geol. 105, 3-41

Sillitoe RH, Jaramillo L, Damon PE, Shafiqullah M, Escovar R, 1982. Setting, characteristics and age of the Andean porphyry copper belt in Colombia. Econ. Geol. 77, 1837-1850

Sillitoe RH, Perello J, 2005. In Hedenquist JW, Thompson JFH, Goldfarb RJ, Richards JP (Eds.), Andean copper province; tectonomagmatic settings, deposit types, metallogeny, exploration, and discovery. Econ. Geol. $100^{\text {th }}$ Anniversary Volume, 845-890

Singer DA, Berger VI, Lenzie WD, Berger BR, 2005. Porphyry copper deposit density. Econ. Geol. $100,491-514$

Singer DA, Berger VI, Moring C, 2008. Porphyry copper deposits of the World: database and grade and tonnage models, 2008. U.S. Geological Survey Open-File Report 2008-1155, 45 p.

Stampfli GM, Borel GD, 2002. A plate tectonic model for the Paleozoic and Mesozoic constrained by dynamic plate boundaries and restored synthetic oceanic isochrons. Earth Planet. Sci. Lett. 196, 17-33

Stampfli GM, Borel GD, 2004. The TRANSMED transects in space and time: constraints on the paleotectonic evolution of the Mediterranean domain. In: Cavazza W., Roure F., Spakman W., Stampfli G.M. and Ziegler P. (Eds.), The TRANSMED Atlas: the Mediterranean Region from Crust to Mantle. Springer Verlag, 53-80

Stegman DR, Farrington R, Capitanio FA, Schellart WP, 2010. A regime diagram for subduction styles from 3D numerical models of free subduction. Tectonophysics, 483, 29-45

Tatsumi Y, Eggins S, 1995. Subduction zone magmatism. Cambridge, MA, Blackwell Science (Ed.), 211 p.

Thiéblemont D, Stein G, Lescuyer JL, 1997. Epithermal and porphyry deposits: the adakite connexion. C. R. Acad. Sci.Paris, 325, 103-109 
Tosdal, R.M., and Richards, J.P., 2001. Magmatic and structural controls on the development of porphyry $\mathrm{Cu} \pm \mathrm{Mo} \pm \mathrm{Au}$ deposits, in Richards, J.P., and Tosdal, R.M., eds., Structural controls on ore genesis: Society of Economic Geologists, Reviews in Economic Geology, v. 14, 157-181

Uyeda S, Kanamori H, 1979. Back-arc opening and the mode of subduction. J. Geophys. Res. 84, 1049-1061

van der Hilst R, Engdahl ER, Spakman W, Nolet G, 1991. Tomographic imaging of subducted lithosphere below west Pacific island arcs. Nature, 357, 37-43

Van Hinsbergen DJJ, Hafkenscheid E, Spakman W, Meulenkamp JE, Wortel R, 2005. Nappe stacking resulting from subduction of oceanic and continental lithosphere below Greece, Geology, 33, 325-328

Volkov AV, Stefanova V, Serafimovski T, Sidorov AA, 2008. Native gold of the porphyry copper mineralization in the Borov Dol deposit (Republic of Macedonia). Dokl. Earth Sci. 422, 10131017

Voudouris PC, Melfos V, Spry PG, Bindi L, Kartal T, Arikas K, Moritz R, Ortelli M, 2009. Rheniumrich molybdenite and rhenite in the Pagoni Rachi Mo-Cu-Te-Ag-Au prospect, northern Greece : implications for the Re geochemistry of porphyry-style Cu-Mo and Mo mineralization. Can. Mineral. 47, 1013-1036

Wortel MJR, Spakman W, 2000. Subduction and slab detachment in the Mediterranean-Carpathian region. Science, 290, 1910-1917

Wright JB (Ed.), 1977. Mineral deposits, continental drift and plate tectonics. Benchmark papers in geology, vol. 44, Dowdon, Hutchinson and Ross, Inc., 418 p.

Yamato P, Husson L, Braun J, Loiselet C, Thieulot C, 2009. Influence of surrounding plates on 3D subduction dynamics. Geophys. Res. Lett., 36, L07303, doi :10.1029/2008GL036942

Yáñez GA, Ranero CR, Von Huene R, Diaz J, 2001. Magnetic anomaly interpretation across the southern central Andes $\left(32^{\circ}-34^{\circ} \mathrm{S}\right)$ : the role of the Juan Fernández ridge in the late Tertiary evolution of the margin. J. Geophys. Res. 106, 6325-6345

Yigit O, 2009. Mineral deposits of Turkey in relation to Tethyan metallogeny : implications for future mineral exploration. Econ. Geol. 104, 19-51 


\section{Appendix 1 - Methodology}

\section{Paleogeographic reconstruction tool}

The paleogeographic software we have used in the present study for paleotectonic reconstructions is PaleoGIS ${ }^{\mathrm{TM}}$. It is a collection of tools that runs under ESRI's ArcGIS ${ }^{\mathrm{TM}}$. It allows, from a plate tectonic model, to create and display paleogeographic (or paleotectonic) reconstructions that include user's datasets (i.e. deposit data of Tables 1 and 2 for the present study), then to manipulate and process paleogeographic data with the tools and functions available or developed within the Geographic Information System. Beside paleotectonic reconstructions of Figure 5, instantaneous velocity fields of Figure 5 and rates versus time for Figures 6 and 8 were calculated using analysis tools provided within PaleoGIS ${ }^{\mathrm{TM}}$.

\section{Plate tectonic models}

Paleogeographic/paleotectonic reconstructions and analyses are based on plate tectonic models. Several models, either commercial or academic, are available. For the present study, we looked for plate models that would satisfy the following criteria:

- Sufficient time span to cover the geneses of porphyry Cu studied in the present paper;

- Published - and as such, peer reviewed - academic models;

- Publicly available at no charge, to be freely and easily used to reproduce our reconstructions and calculations.

We selected two global plate tectonic models that satisfy these criteria, the UTIG PLATES and Earthbyte models.

The UTIG PLATES model (http://www.ig.utexas.edu/research/projects/plates/) has been developed by the University of Texas Institute for Geophysics at Austin. It covers the whole Earth, with 502 polygons, and goes back to 750 Myrs from the past (Neoproterozoic). A major purpose of this model is to provide a powerful tool for reconstructing detailed geological environments "to groups engaged in exploration for hydrocarbons or minerals on global and regional scales". It is based on comprehensive oceanic paleomagnetic and tectonic database, from which is derived a detailed database of finite-difference poles of rotations.

The Earthbyte model (http://www.earthbyte.org/) has been developed by the Earthbyte group, "research groups for global and regional plate tectonic reconstructions and for studying the interplay between the deep earth and surface processes", to be used with its open-source paleogeographic reconstruction software GPlates. The model covers the whole Earth, with 1480 polygons, and goes back to 140 Myrs from the past (Lower Cretaceous). It is based on ocean magnetic anomalies, fracture zones, geometry of plate boundaries and numerous geological datasets. The absolute reference for plate displacements is the hotspots reference frame. The large number of polygons in the model makes it relatively accurate but may generate artifacts in relative plate displacements (see, for instance, short time scale velocity peaks at $\sim 55 \mathrm{Ma}$ in Figure 
6), as it significantly complicates plate hierarchy.

One should keep in mind, however, that both plate tectonic models are global and their accuracy may be limited at a regional scale. For that reason, we have only calculated from them first-order relative displacements and positions of major plates and blocs. 


\section{Figure 1}

a) Western Tethyan subduction zone

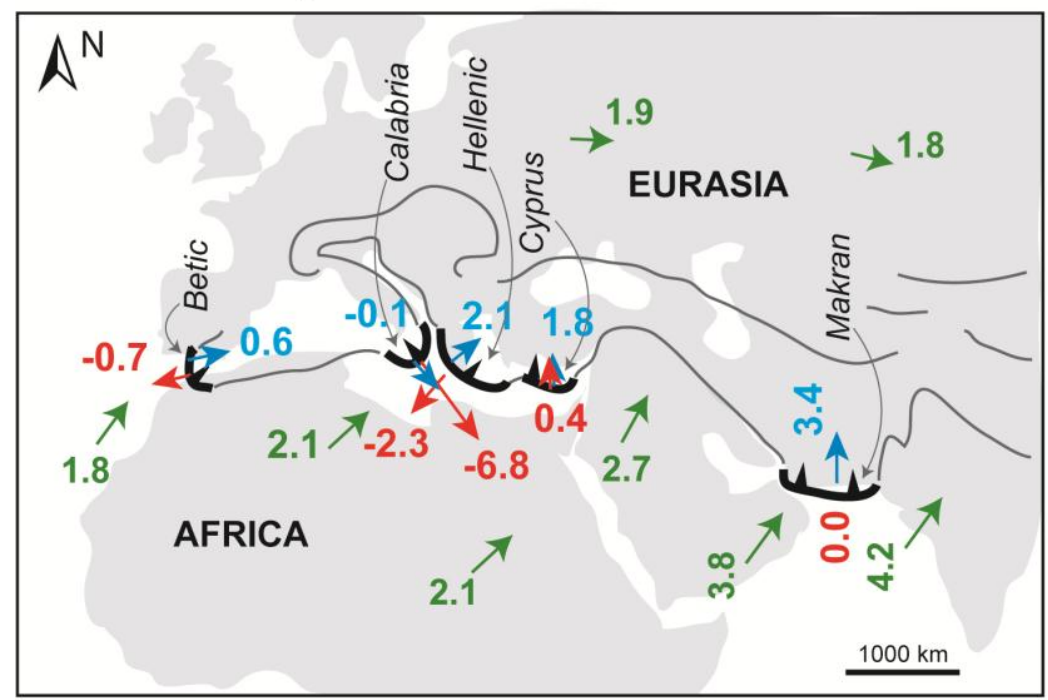

b) Andean subduction zone

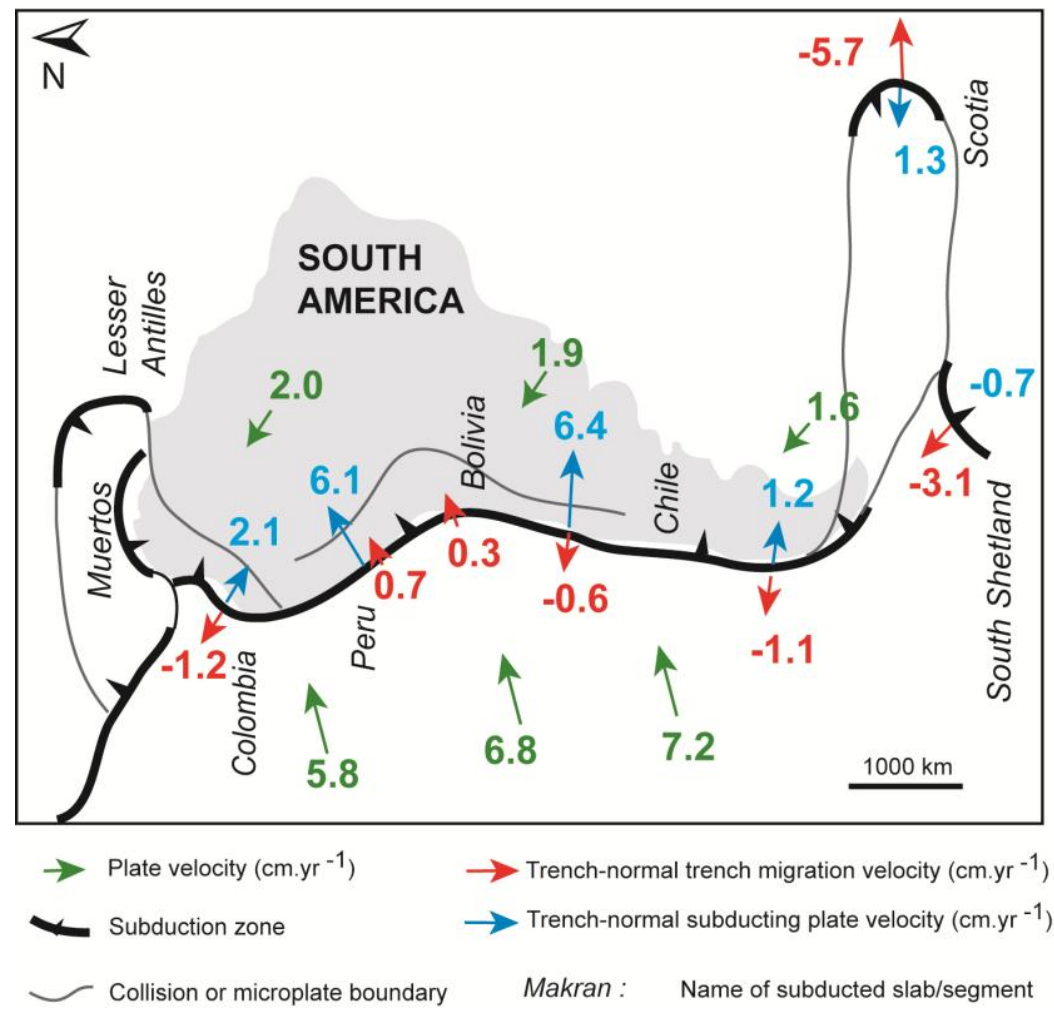

Figure 1 - Schematic maps of the two studied subduction zones with plate velocities (green), trench-normal trench migration velocities (red) and trench-normal subducting plate velocities (blue), as calculated with the Indo-Atlantic hotspot reference frame from O'Neill et al. (2005). a) Present-day western Tethyan subduction zone, showing five narrow segments of curved subducted slabs, 500-1000 km long; b) Present-day Andean subduction zone mainly composed of one single 7,500 km - long segment. Modified after Schellart et al. (2011). 


\section{Figure 2}

a)
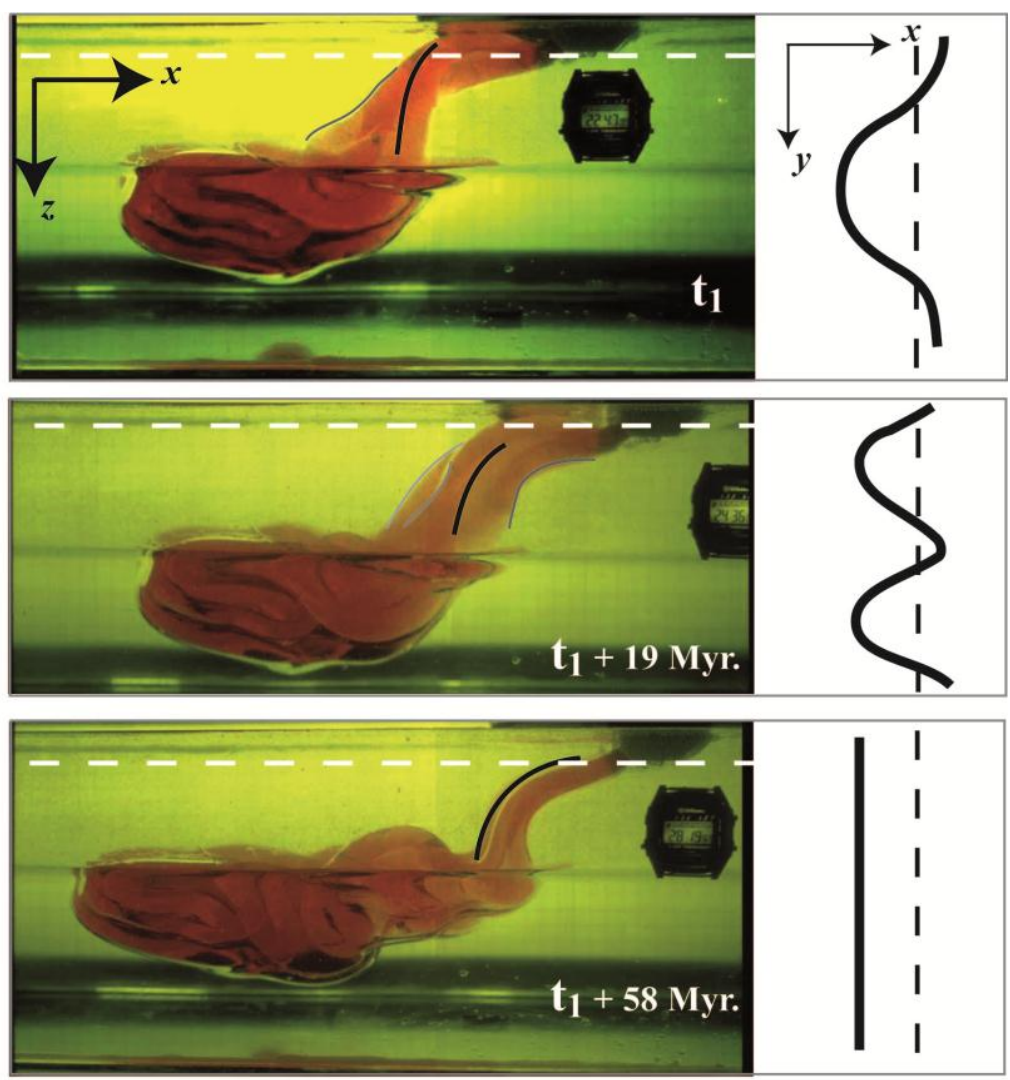

b)
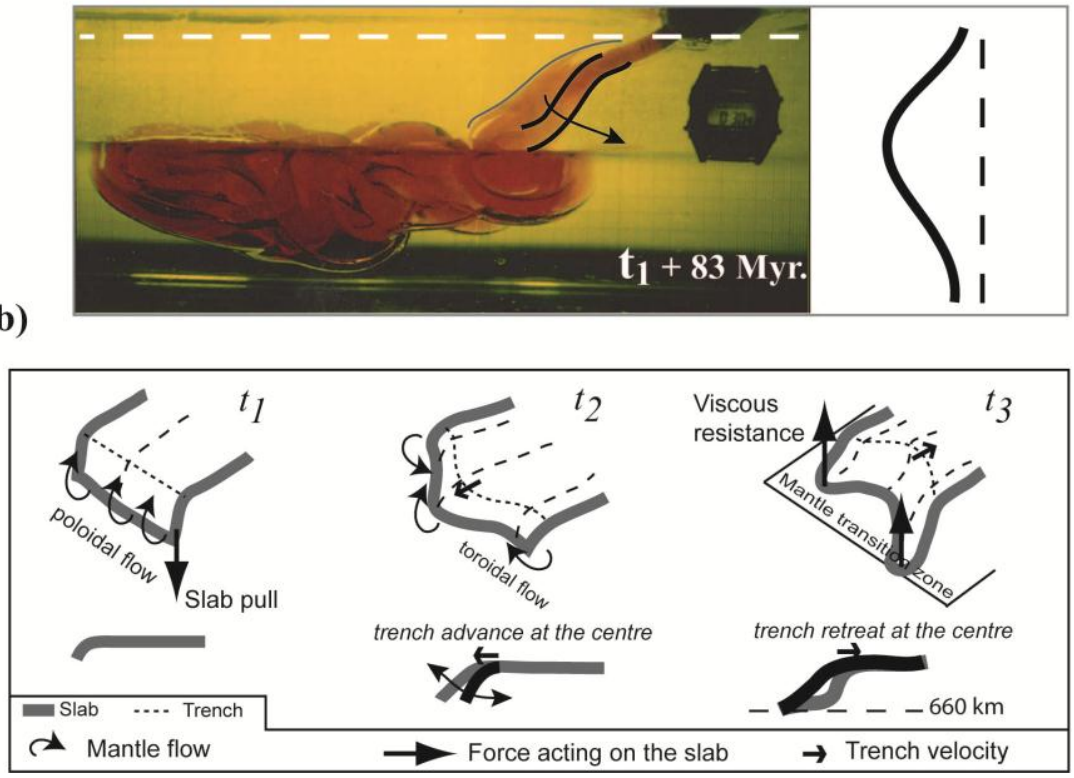

Figure 2 - a) Laboratory experiment number 13 from Guillou-Frottier et al. (1995), where lateral undulations (perpendicular to pictures) are underlined by black (front) and grey (back) lines, and illustrated by thick black lines at the right of each picture corresponding to horizontal crosssections (at the level of dashed white lines); b) From left to right, temporal evolution of the 3D shape during the buckling behavior (lateral and vertical folding) of a subducting lithosphere, with implications for trench retreat or advance. 


\section{Figure 3}

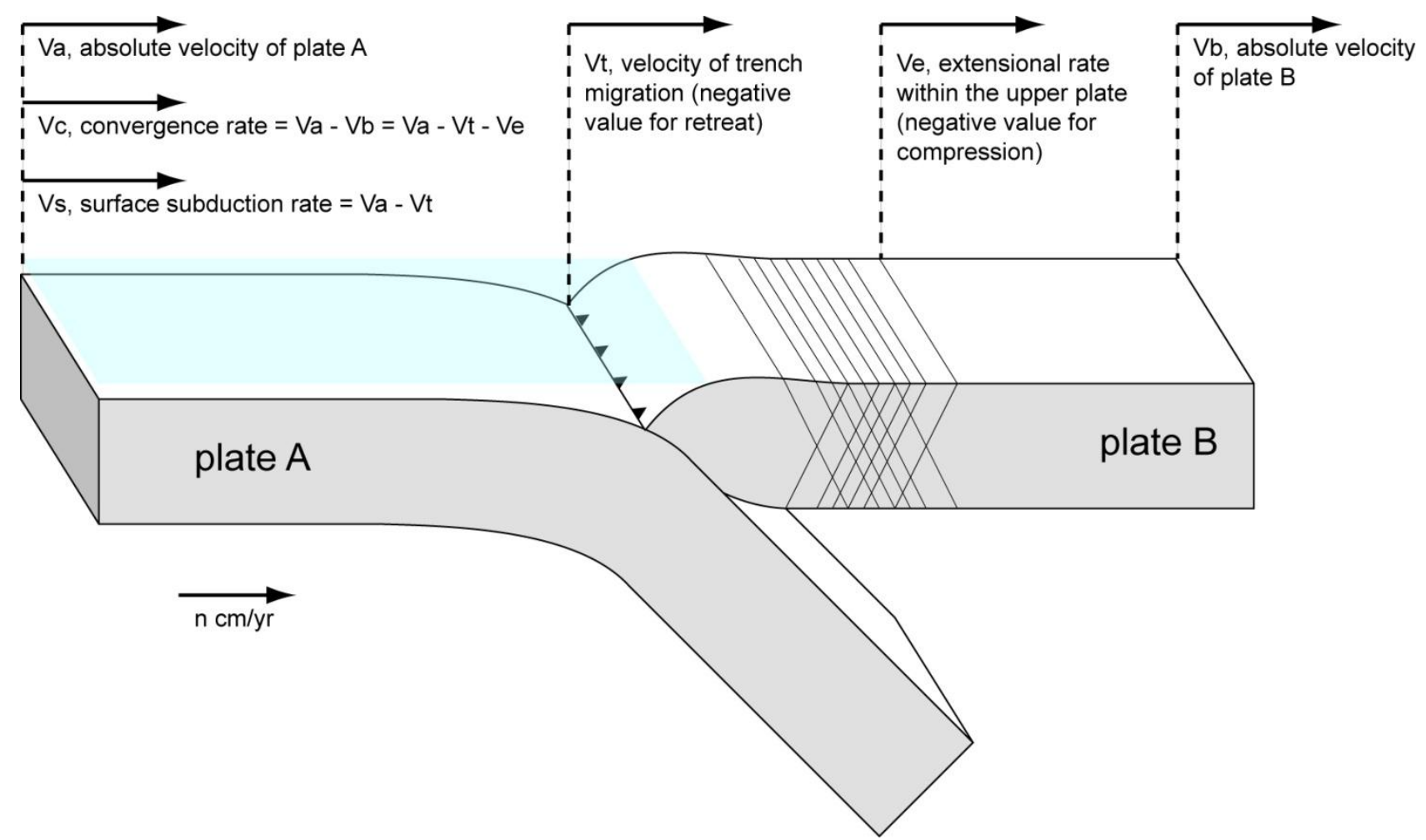

Figure 3 - Definition of convergence and subduction rates (Vc and Vs respectively), considering absolute plate motions ( $\mathrm{Va}$ and $\mathrm{Vb}$ ), absolute trench velocity $(\mathrm{Vt})$ and extensional rate within the upper plate $(\mathrm{Ve})$. For the sake of clarity, velocities are here considered horizontal and perpendicular to the trench, but oblique convergence is included in the kinematic reconstructions. Directions and lengths of arrows are arbitrarily chosen. 


\section{Figure 4}

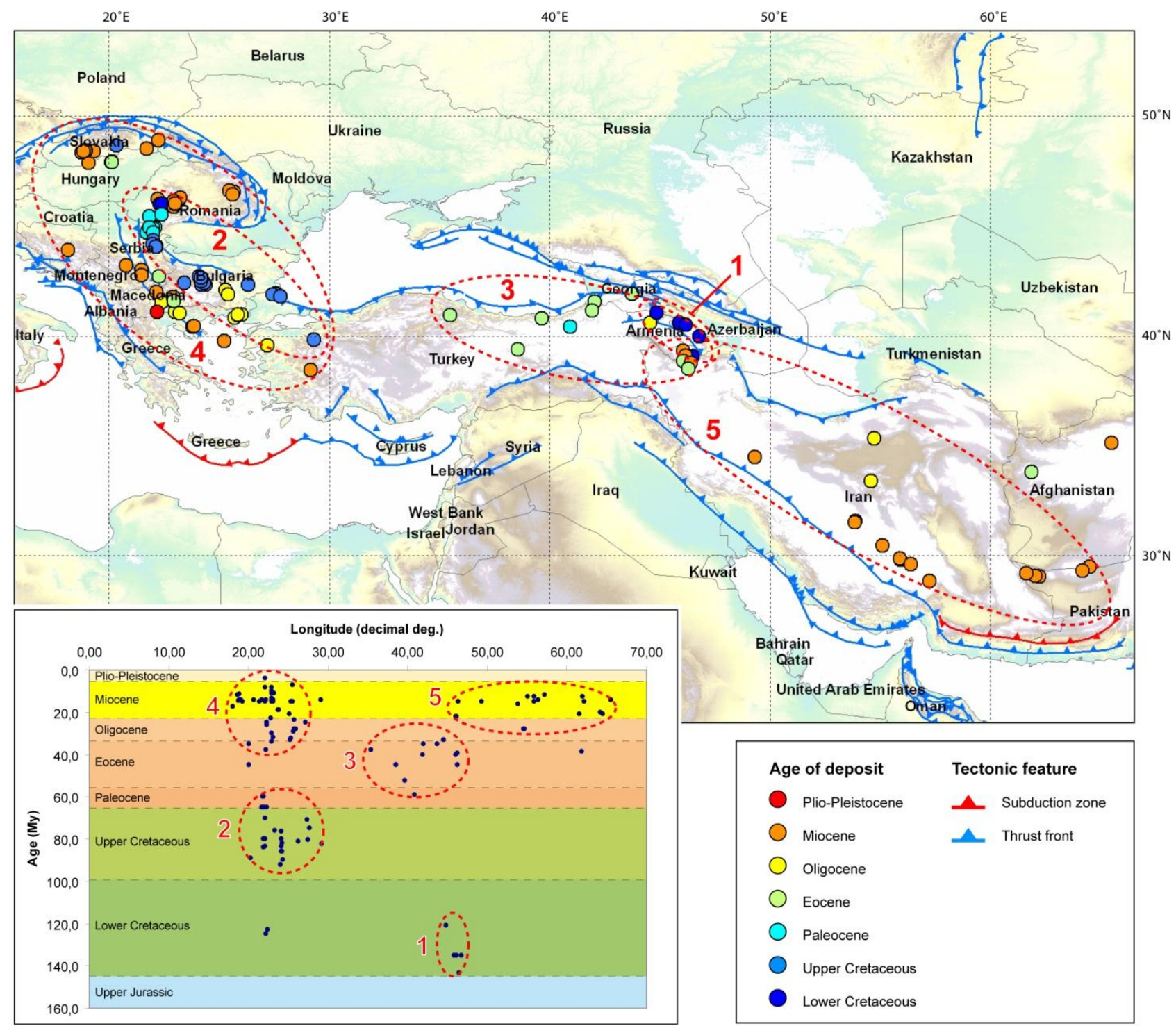

Figure 4 - Spatial and temporal distribution of porphyry copper deposits along the western Tethyan suture. a) Present day map of the distribution of mineralization as a function of their age, from Lower Cretaceous to Plio-Pleistocene. b) Longitudinal section of deposit distribution as a function of age of mineralization. In both representations, we define five distinct clusters (red dashed ellipse) (see text for details). 


\section{Figure 5}

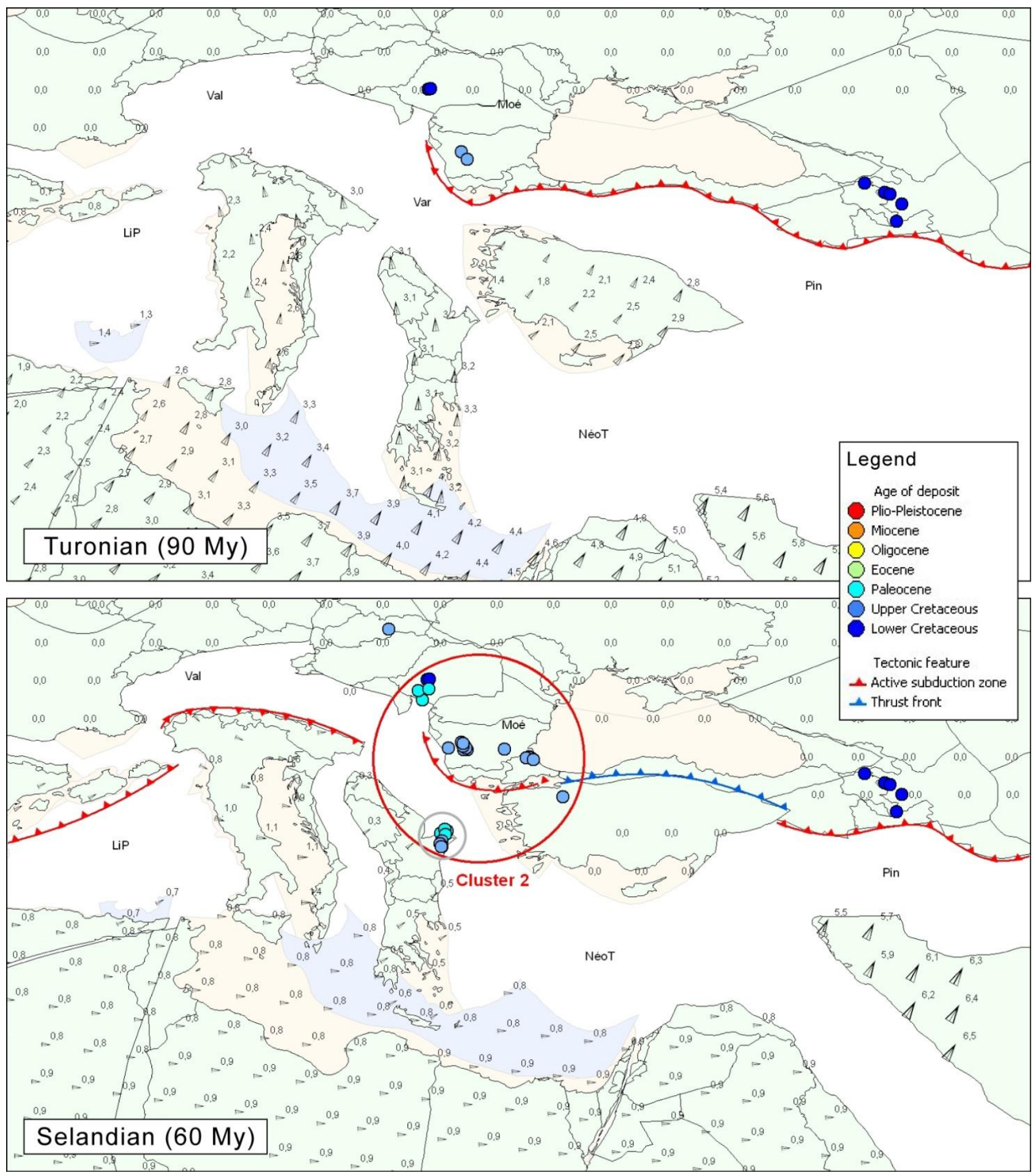

Figure $5 a-$ Paleotectonic reconstructions and instantaneous velocity field of the western Tethys region in Turonian (top) and Selandian (bottom), using the UTIG PLATES global kinematic model (see Appendix 1). Eurasia is considered stable (fixed plate). Appearance of deposits in the subducting plate (small light grey circle) is a bias due to inaccurate plate boundary definition in the original plate tectonic model. Val: Valaisan ocean; LiP: LiguroPiemontese ocean; Moe: Moesian platform; Var: Vardar ocean; Pin: Pindos ocean; NeoT: Neotethys ocean. 


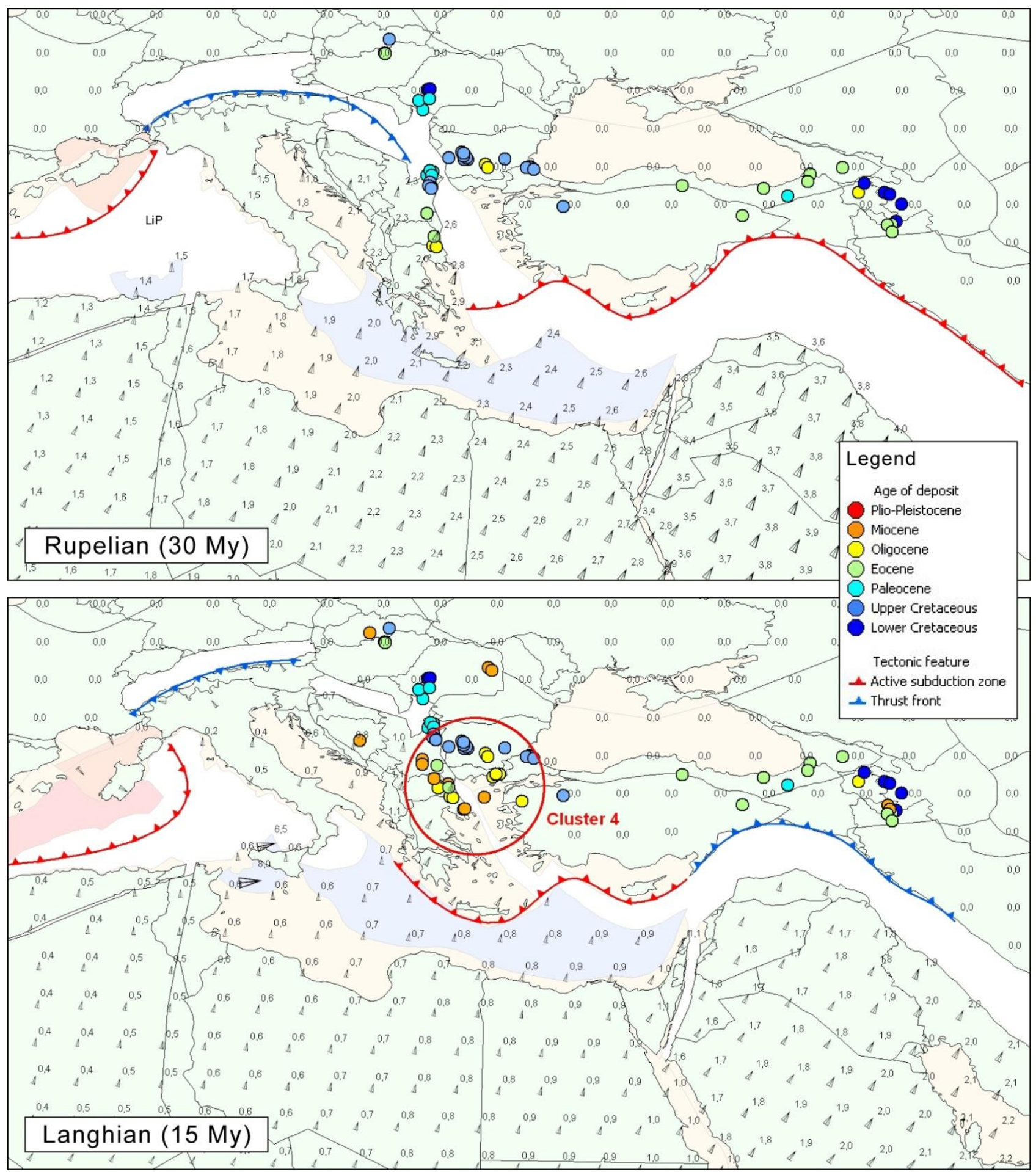

Figure $5 b$ - Paleotectonic reconstructions and instantaneous velocity field of the western Tethys region in Rupelian (top) and Langhian (bottom), using the UTIG PLATES global kinematic model. Eurasia is considered stable (fixed plate). LiP: Liguro-Piemontese ocean. 


\section{Figure 6}

Western Tethyan suture, convergence rate vs. time of Africa relative to Eurasia

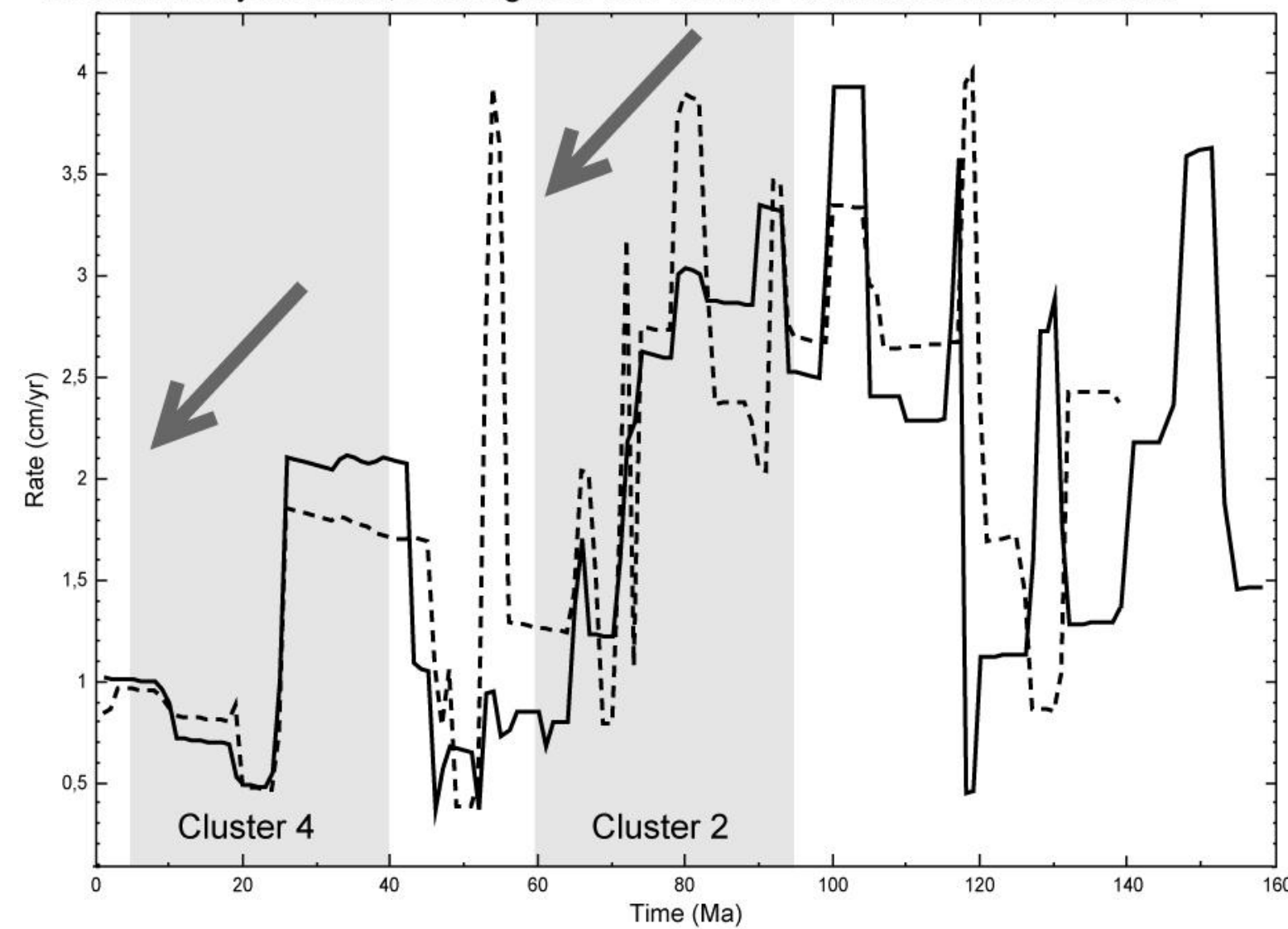

Africa plate $\left(33^{\circ} \mathrm{N} / 19^{\circ} \mathrm{E}\right)$, UTIG PLATES model Africa plate $\left(33^{\circ} \mathrm{N} / 19^{\circ} \mathrm{E}\right)$, EarthByte model

Displacements relative to stable Eurasia

Figure 6 - Rates of convergence versus time of the Africa plate relative to fixed Eurasia, showing the kinematic context in which porphyry $\mathrm{Cu}$ deposit clusters were emplaced (light grey areas) along the western Tethyan suture in the Aegean-Balkan-Carpathian region since Cretaceous; grey arrows show long time-scale slowing down of convergence rates. 


\section{Figure 7}

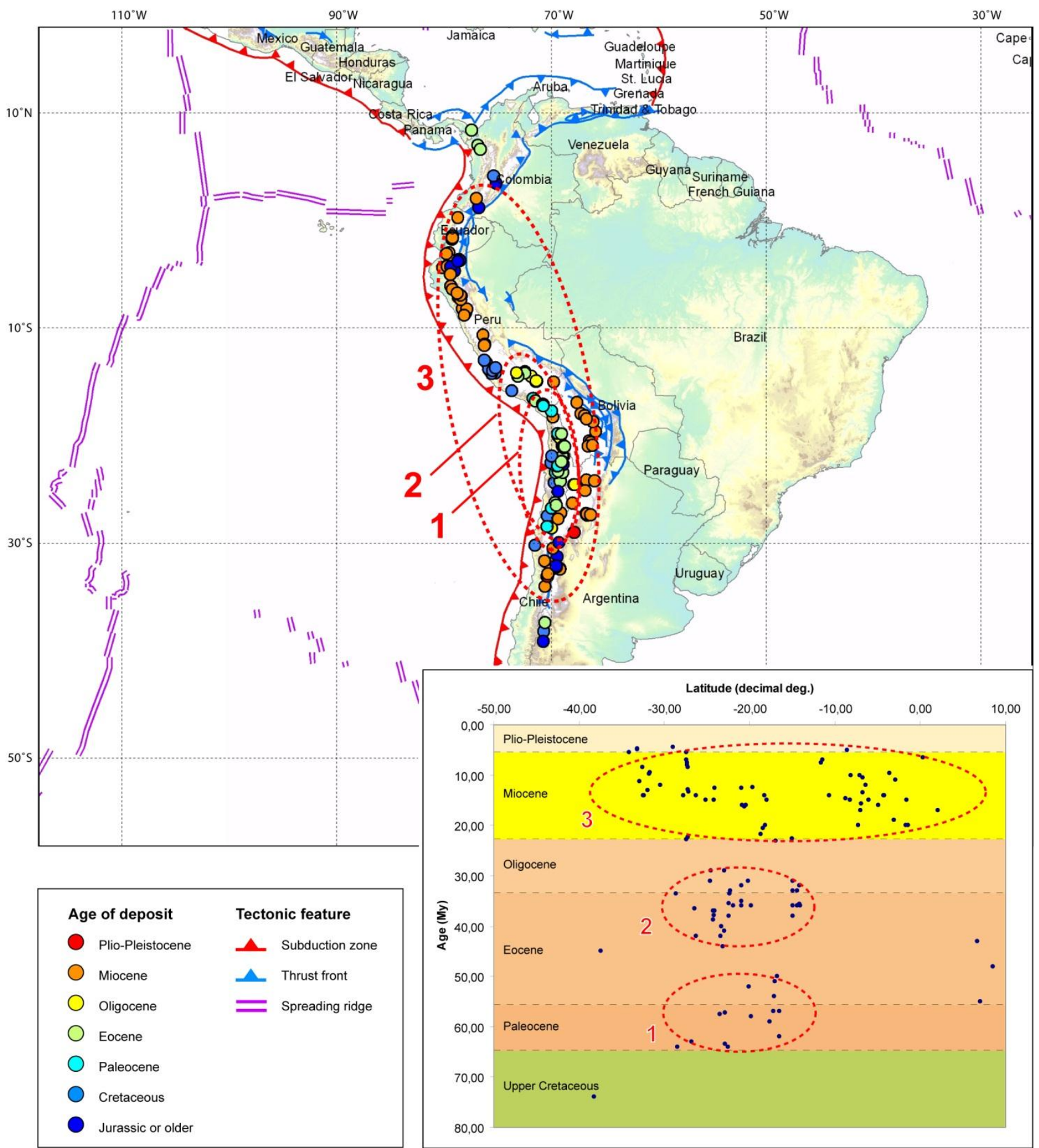

Figure 7 - Spatial and temporal distribution of porphyry $\mathrm{Cu}$ deposits along the Andean subduction. a) Present day map of the distribution of mineralization as a function of their age, from Jurassic to Plio-Pleistocene. b) Longitudinal section of deposit distribution as a function of age of mineralization. In both representations, we define three distinct clusters (red dashed ellipse) (see text for details). 


\section{Figure 8}

Andean subduction, convergence rate vs. time of Nazca plate relative to south America

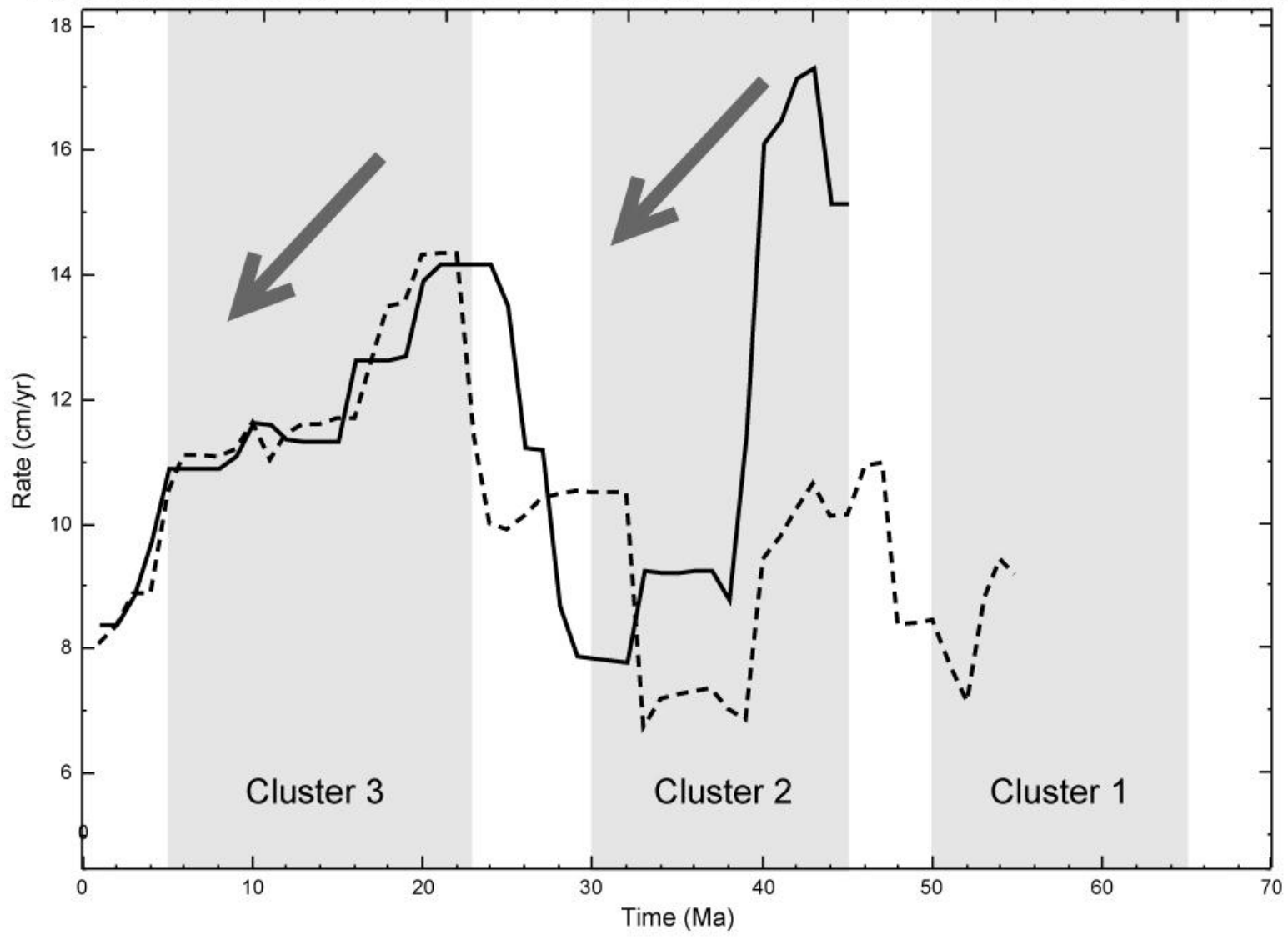

- Nazca plate $\left(20^{\circ} \mathrm{S} / 72^{\circ} \mathrm{W}\right)$, UTIG PLATES model

Displacements relative Nazca plate $\left(20^{\circ} \mathrm{S} / 72^{\circ} \mathrm{W}\right)$, EarthByte model

Figure 8 - Rates of convergence versus time of the Nazca plate relative to fixed South America, showing the kinematic context in which porphyry $\mathrm{Cu}$ deposit clusters were emplaced (light grey areas) along the Andean subduction since Eocene; grey arrows show long time scale slowing down of convergence rates. 


\section{Figure 9}
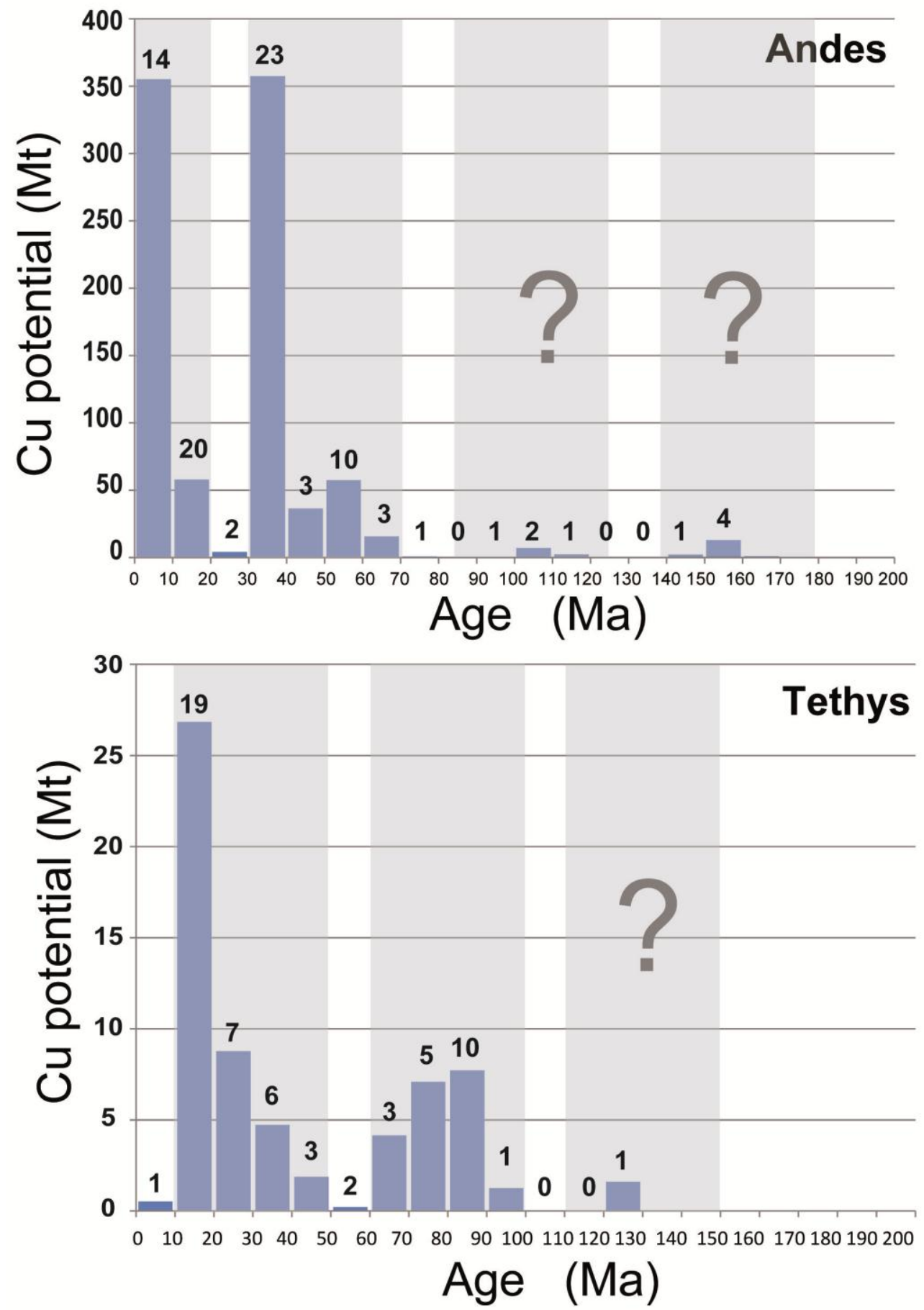

Figure $9-\mathrm{Cu}$ potential (in Mt of metal) for the Andean and Tethyan subduction zones as a function of age (Ma). Temporal clusters are highlighted with grey shadings. Numbers of significant deposits (classes $\mathrm{A}$ to $\mathrm{C}$, see Table 1 and 2) are indicated on top of each bar. 


\section{Figure 10}
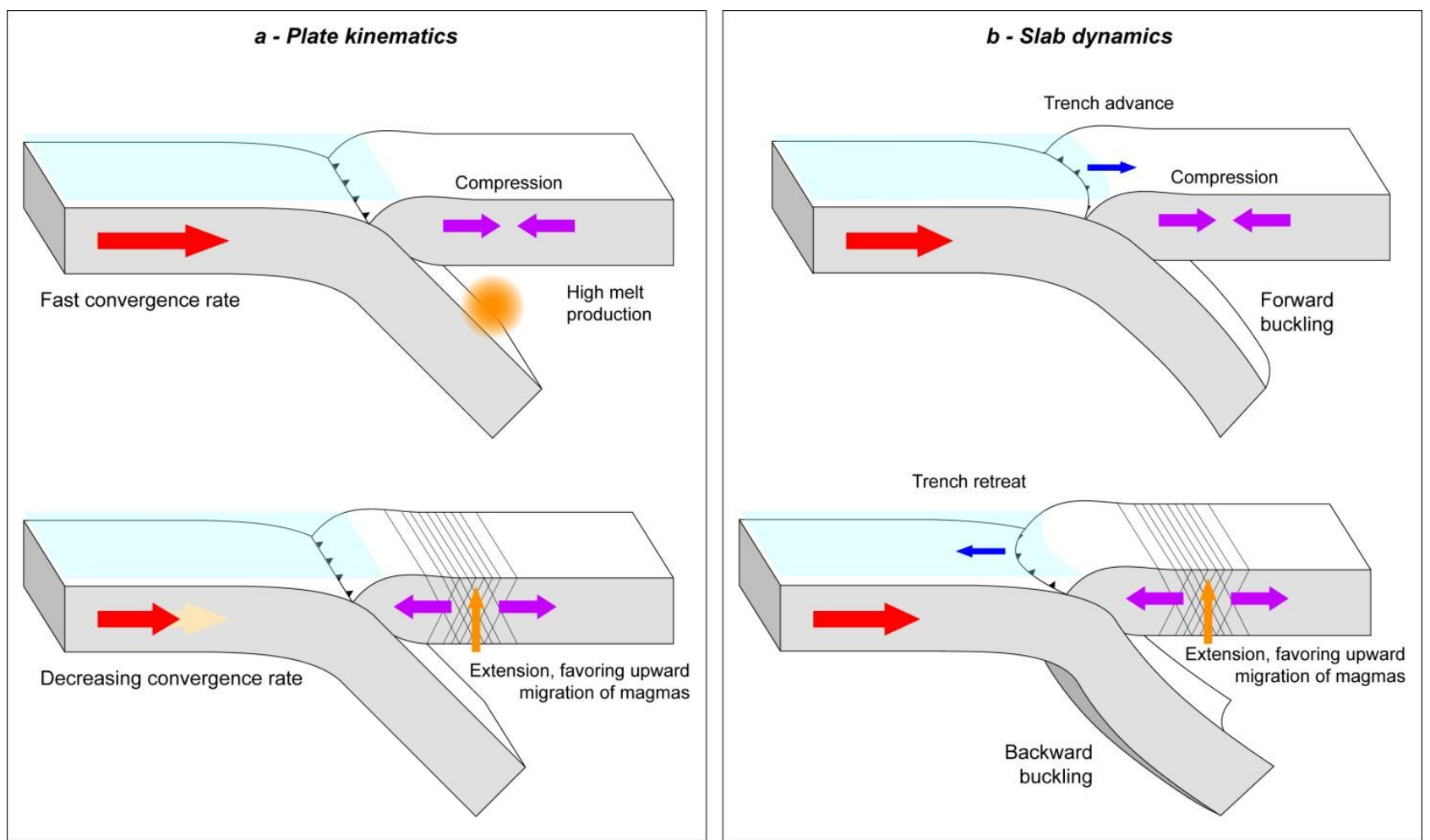

Figure 10 - Conceptual geodynamic models suggesting distinct processes favoring porphyry $\mathrm{Cu}$ deposits formation. a) Influence of the plate kinematics (i.e. fast then decreasing convergence rate) on overriding plate deformation (i.e. compression followed by extension), magma production and migration. b) Influence of slab dynamics on overriding plate deformation: forward slab buckling promotes trench advance and compression in the overriding plate (top), while backward slab buckling promotes trench retreat, extension in the overriding plate and upward magma migration (bottom). In both cases, the overriding plate is fixed. 


\begin{tabular}{|c|c|c|c|c|c|}
\hline Country & $\begin{array}{c}\text { Name of } \\
\text { deposit }\end{array}$ & $\begin{array}{c}\text { Long } \\
\left({ }^{\circ} \mathrm{E}\right)\end{array}$ & $\begin{array}{l}\text { Lat } \\
\left({ }^{\circ} \mathrm{N}\right)\end{array}$ & $\begin{array}{c}\text { Cu } \\
\text { class }\end{array}$ & $\begin{array}{c}\text { Age of } \\
\text { minera- } \\
\text { lization } \\
\text { (Myr) }\end{array}$ \\
\hline \multirow{2}{*}{$\begin{array}{l}\text { Afgha- } \\
\text { nistan }\end{array}$} & Okhan-Kashan & 65,50 & 35,19 & D & 14,0 \\
\hline & Shaida & 61,85 & 33,85 & D & 38,5 \\
\hline \multirow{6}{*}{ 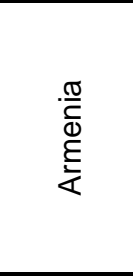 } & Agarak & 46,22 & 38,93 & $C$ & 39,5 \\
\hline & Ankavan & 44,52 & 40,63 & & 33,0 \\
\hline & Dastakert & 46,03 & 39,37 & & 22,0 \\
\hline & Kadgaran & 46,13 & 39,15 & B & 22,0 \\
\hline & Shikahoh & 46,47 & 39,10 & & 143,5 \\
\hline & Tekhut & 44,82 & 41,11 & B & 121,0 \\
\hline \multirow{4}{*}{$\begin{array}{l}\frac{c}{0} \\
: \frac{\pi}{\bar{\pi}} \\
\frac{0}{\bar{D}} \\
\frac{N}{<}\end{array}$} & Damirli & 46,75 & 40,02 & & 135,0 \\
\hline & Garadag & 45,85 & 40,63 & & 135,0 \\
\hline & Goshgarchai & 46,15 & 40,53 & & 135,0 \\
\hline & $(c$ & 46,02 & 38,90 & $\mathrm{~B}$ & 40,0 \\
\hline \multirow{2}{*}{$\begin{array}{l}\text { Bosnia } \\
\text { and } \\
\text { Herze- } \\
\text { govina }\end{array}$} & & & & & \\
\hline & Kiseljak & 18,08 & 43,94 & C & 17,5 \\
\hline \multirow{16}{*}{ 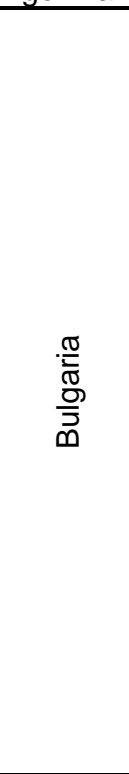 } & Assarel & 24,14 & 42,55 & $B$ & 76,5 \\
\hline & Bardtzeto & 27,52 & 41,99 & & 80,5 \\
\hline & Briastovo & 25,37 & 41,94 & D & 32,5 \\
\hline & Byrdtseto & 27,53 & 41,97 & & 80,5 \\
\hline & Elatsite & 24,04 & 42,75 & B & 92,1 \\
\hline & Karlievo & 24,12 & 42,69 & C & 86,0 \\
\hline & Kominsko & 2 & 4246 & $\mathrm{~F}$ & 860 \\
\hline & $\begin{array}{l}\text { Chukar } \\
\text { Medet }\end{array}$ & $\begin{array}{l}24,20 \\
24,19\end{array}$ & $\begin{array}{l}42,46 \\
42,60\end{array}$ & $\begin{array}{l}\mathrm{c} \\
\mathrm{C}\end{array}$ & 80,0 \\
\hline & Orlovo Gnezdo & 24,13 & 42,54 & C & 86,0 \\
\hline & Petelovo & 24,27 & 42,46 & $\mathrm{E}$ & 86,0 \\
\hline & Popovo Dere & 24,16 & 42,37 & C & 83,5 \\
\hline & Prohorovo & 26,25 & 42,37 & C & 81,0 \\
\hline & Spahievo & 25,25 & 42,12 & & 33,0 \\
\hline & Studenets & 23,36 & 42,46 & & 76,0 \\
\hline & Tsar Asen & 24,34 & 42,36 & C & 90,0 \\
\hline & Vlaikov Vruh & 24,21 & 42,35 & D & 82,0 \\
\hline \multirow{2}{*}{ Georgia } & Garta & 43,70 & 41,94 & C & 35,0 \\
\hline & Merisi (gr & 42,01 & 41,59 & & 35,0 \\
\hline \multirow{9}{*}{$\begin{array}{l}\mathbb{\Xi} \\
\mathbb{\Phi} \\
\mathbb{N} \\
\mathbb{U}\end{array}$} & Fakos & 25,19 & 39,81 & & 21,0 \\
\hline & Fisoka & 23,79 & 40,50 & $\mathrm{D}$ & 19,0 \\
\hline & Kassiteres & 25,79 & 41,02 & & 23,5 \\
\hline & Maronia & 25,64 & 40,88 & & 29,0 \\
\hline & Mili & 25,97 & 41,01 & & 28,0 \\
\hline & Pagoni Rachi & 25,81 & 41,00 & & 28,0 \\
\hline & Pontokerasia & 23,15 & 41,07 & & 32,0 \\
\hline & Skouries & 23,73 & 40,46 & C & 19,0 \\
\hline & Kilkis & 22,97 & 41,13 & & 30,0 \\
\hline 동 즁 & \begin{tabular}{|l|} 
Bsrzssny \\
Mountains
\end{tabular} & 19,03 & 47,92 & & 14 \\
\hline
\end{tabular}

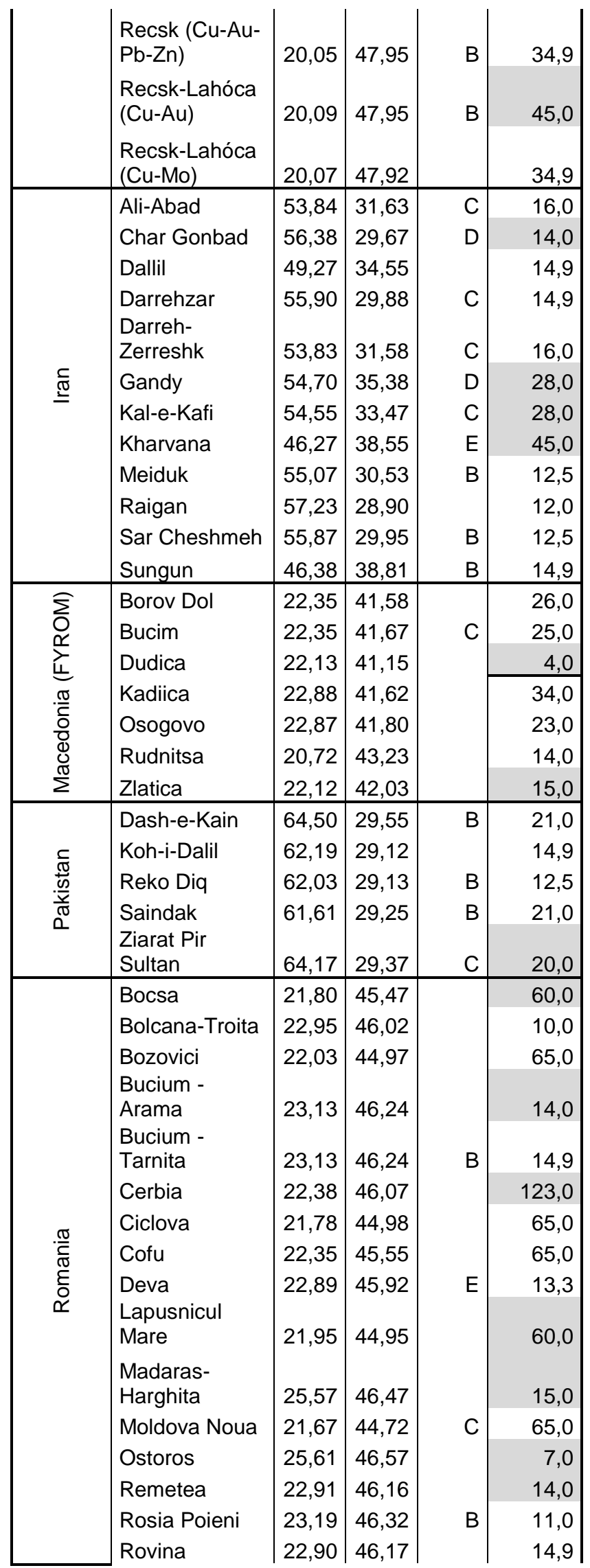




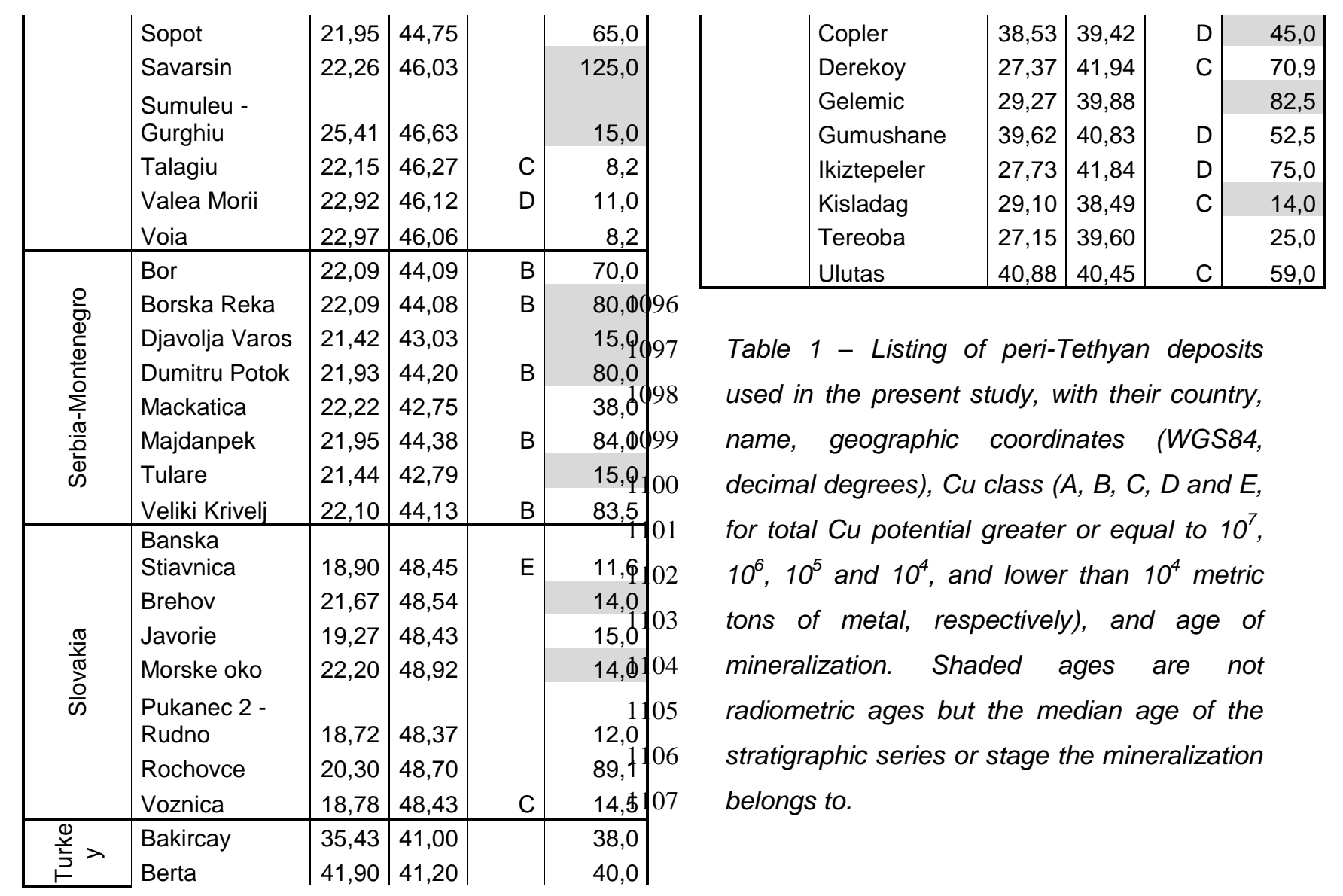




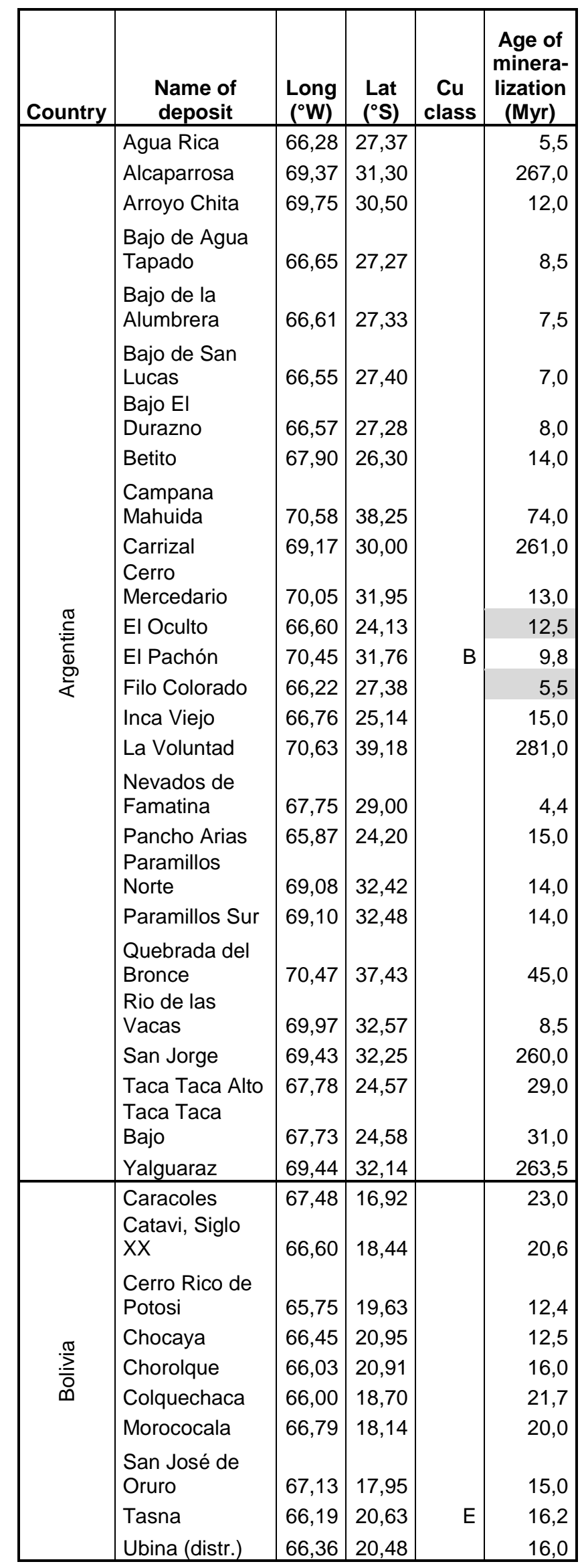

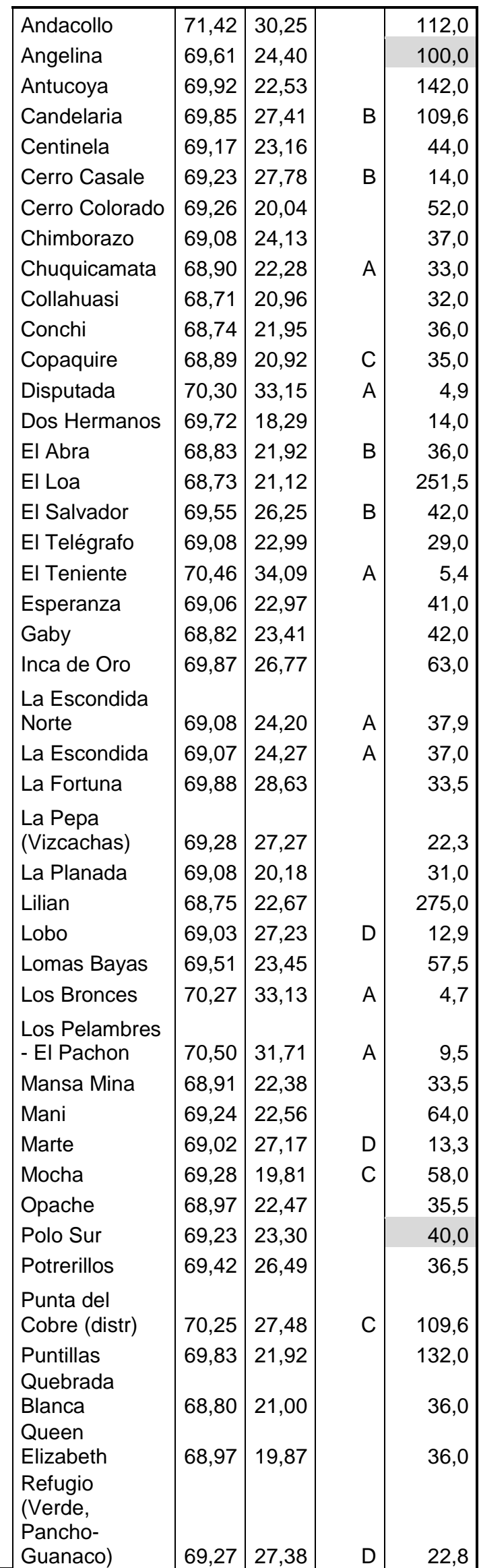




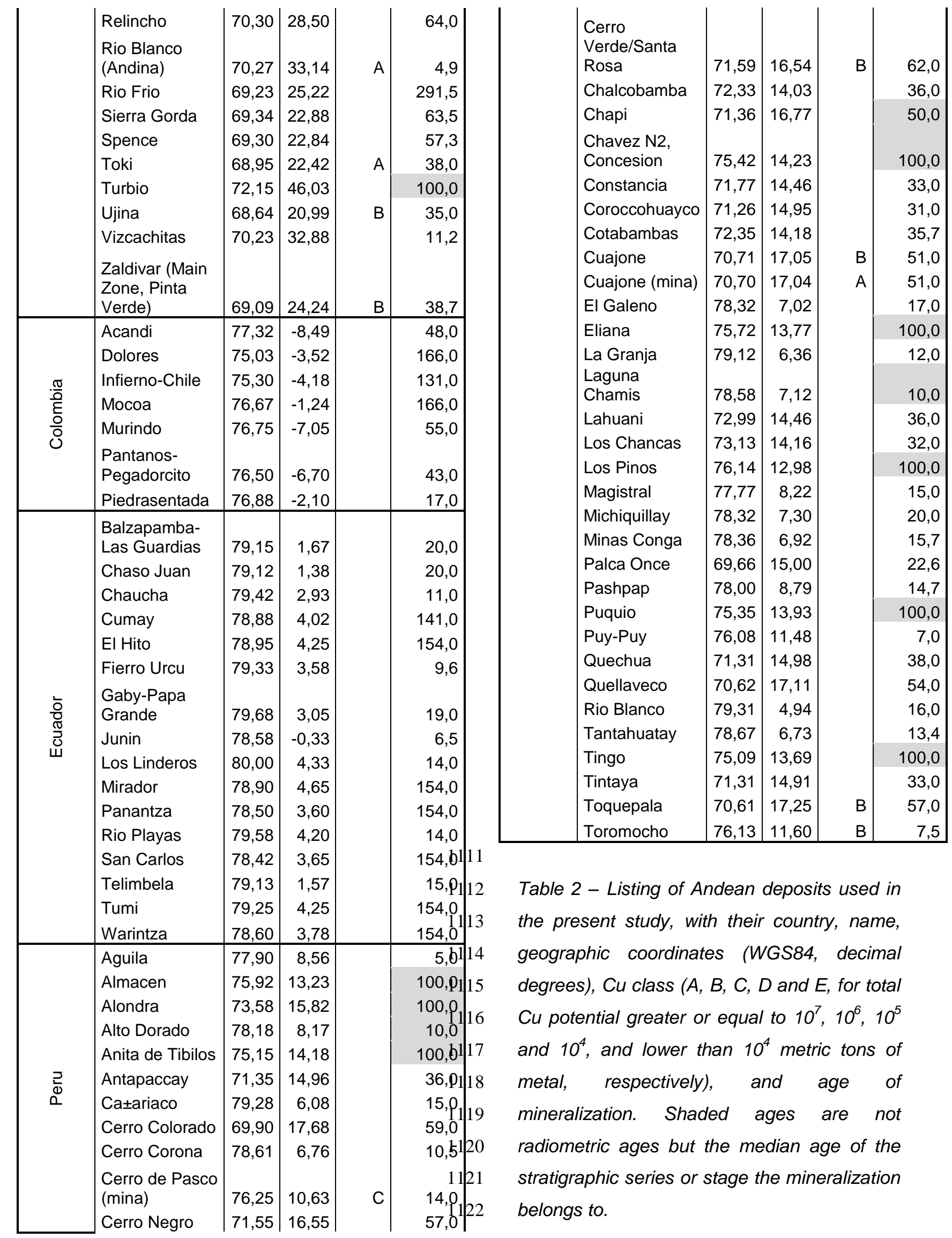




\section{Highlights}

- A paleotectonic approach is used to study the genesis of porphyry Cu deposits

- Deposits along the Tethyan and Andean margins form spatial and temporal clusters

- Four clusters are related to similar plate convergence paleokinematic contexts

- Rapid then decreasing convergence rates favor the genesis of porphyry Cu deposits

- Changes in plate kinematics or slab dynamics may trigger barren time periods 